\title{
Copper-Chitosan Nanocomposite Hydrogels Against Aflatoxigenic Aspergillus flavus from Dairy Cattle Feed
}

\author{
Kamel A. Abd-Elsalam ${ }^{1, *(1)}$, Mousa A. Alghuthaymi ${ }^{2}$, Ashwag Shami ${ }^{3, *(0)}$, \\ Margarita S. Rubina ${ }^{4}$, Sergey S. Abramchuk ${ }^{4}$, Eleonora V. Shtykova ${ }^{5}$ and \\ Alexander Yu. Vasil'kov ${ }^{4}$ (D) \\ 1 Plant Pathology Research Institute, Agricultural Research Center (ARC), 9-Gamaa St., Giza 12619, Egypt \\ 2 Biology Department, Science and Humanities College, Shaqra University, Alquwayiyah 19245, Saudi Arabia; \\ malghuthaymi@su.edu.sa \\ 3 Biology Department, College of Sciences, Princess Nourah bint Abdulrahman University, Riyadh 11543, \\ Saudi Arabia \\ 4 A.N. Nesmeyanov Institute of Organoelement compounds (INEOS) of Russian Academy of 13 Sciences, \\ 119454 Moscow, Russia; margorubina@yandex.ru (M.S.R.); abr@polly.phys.msu.ru (S.S.A.); \\ alexandervasilkov@yandex.ru (A.Y.V.) \\ 5 V. Shubnikov Institute of Crystallography of Federal Scientific Research Centre "Crystallography and \\ Photonics" of Russian Academy of Sciences, 119333 Moscow, Russia; shtykova@ns.crys.ras.ru \\ * Correspondence: kamelabdelsalam@gmail.com (K.A.A.-E.); AYShami@pnu.edu.sa (A.S.); \\ Tel.: +20-10-910-49161 (K.A.A.-E.); +966-11-823-3175 (A.S.)
}

Received: 29 June 2020; Accepted: 16 July 2020; Published: 21 July 2020

check for updates

\begin{abstract}
The integration of copper nanoparticles as antifungal agents in polymeric matrices to produce copper polymer nanocomposites has shown excellent results in preventing the growth of a wide variety of toxigenic fungi. Copper-chitosan nanocomposite-based chitosan hydrogels (Cu-Chit/NCs hydrogel) were prepared using a metal vapor synthesis (MVS) and the resulting samples were described by transmission electron microscopy (TEM), X-ray fluorescence analysis (XRF), and small-angle $X$-ray scattering (SAXS). Aflatoxin-producing medium and VICAM aflatoxins tests were applied to evaluate their ability to produce aflatoxins through various strains of Aspergillus flavus associated with peanut meal and cotton seeds. Aflatoxin production capacity in four fungal media outlets revealed that 13 tested isolates were capable of producing both aflatoxin B1 and B2. Only 2 A. flavus isolates (Af11 and Af 20) fluoresced under UV light in the A. flavus and parasiticus Agar (AFPA) medium. PCR was completed using two specific primers targeting aflP and aflA genes involved in the synthetic track of aflatoxin. Nevertheless, the existence of aflP and aflA genes indicated some correlation with the development of aflatoxin. A unique DNA fragment of the expected $236 \mathrm{bp}$ and $412 \mathrm{bp}$ bands for aflP and aflA genes in A. flavus isolates, although non-PCR fragments have been observed in many other Aspergillus species. This study shows the antifungal activity of $\mathrm{Cu}-\mathrm{Chit} / \mathrm{NCs}$ hydrogels against aflatoxigenic strains of A. flavus. Our results reveal that the antifungal activity of nanocomposites in vitro can be effective depending on the type of fungal strain and nanocomposite concentration. SDS-PAGE and native proteins explain the apparent response of cellular proteins in the presence of $\mathrm{Cu}-\mathrm{Chit} / \mathrm{NC}$ s hydrogels. A. flavus treated with a high concentration of $\mathrm{Cu}-\mathrm{Chit} / \mathrm{NCs}$ hydrogels that can decrease or produce certain types of proteins. $\mathrm{Cu}-\mathrm{Chit} / \mathrm{NC}$ hydrogel decreases the effect of G6DP isozyme while not affecting the activity of peroxidase isozymes in tested isolates. Additionally, microscopic measurements of scanning electron microscopy (SEM) showed damage to the fungal cell membranes. $\mathrm{Cu}-\mathrm{Chit} / \mathrm{NC}_{\mathrm{S}}$ hydrogel is an innovative nano-biopesticide produced by MVS is employed in food and feed to induce plant defense against toxigenic fungi.
\end{abstract}


Keywords: aflatoxins; Aspergillus section Flavi; chitosan; feeds; nanocomposites

\section{Introduction}

The contamination of agricultural and dairy products with aflatoxins is a major problem for economic and public health. Aflatoxins (AFs) are fungal subsidiary products mainly developed by Aspergillus flavus and Aspergillus parasiticus strains on cereals, nuts, dried fruits, dairy, and animal feed under warm and humid conditions [1,2]. The significant source of AFs spoilage is A. flavus, especially aflatoxin B1, which has received a lot of attention in the food and feed industry [3]. High concentrations of aflatoxin could even prompt the disease of aflatoxicosis, an infection that affects serious disease and can lead to cancer in severe cases [1,4,5]. Additionally, chronic absorption of aflatoxins causes various adverse effects, such as increased susceptibility to various pathogens, loss of production, and a decrease in milk production yield and quality in dairy cattle [6]. The nanotechnology approach seems to be an encouraging, effective, and affordable way to reduce the health problems of mycotoxins in humans and animals. There are three different approaches to reduce mycotoxin risks: effects on mold and flour retention, mycotoxin, and minimization of toxic effects by various nanomaterials [7-9]. Chitosan and self-assembled benzoic acid polymers were synthesized, and it was found that the encapsulation of CS-BA nanogels significantly enhanced the half-life and antifungal activity properties of thyme oil against $A$. flavus strains [10]. The antifungal efficacy of mycogenic silver nanoparticles hybridizing with simvastatin against three species of the Aspergillus Flavi group was measured. Some nano-formulations regulated the development of the toxigenic Aspergillus species [11]. Plant-mediated $\mathrm{CuO}$ NPs were synthesized from Cissus quadrangularis and applied as antifungal agents against $A$. niger and $A$. flavus. The produced nano-copper showed a better performance than the carbendazim fungicide [12]. In addition, hybrid nanocomposites based on organic polymeric and inorganic matrices as effective anti-aflatoxigenic strains were explored $[3,4,13,14]$. Chitosan-based nanocomposite film vapor assays were applied to hybrids between thyme-organo, thyme-tea tree, and thyme-peppermint EO mixtures and demonstrated strong antifungal action against some toxic fungi, including A. flavus, A. parasiticus, and P. chrysogenum, limiting their production ranged from 51 to $77 \%$ [15]. There is a direct association between the concentration of aflatoxin M1 (AFM1) in milk and aflatoxin B1 (AFB1) in dairy cattle feed which results in AFM1 being found in the milk of animals on contaminated feeds with AFB1 [16]. To our understanding, antifungal action of copper-chitosan nanocomposite-based chitosan hydrogels ( $\mathrm{Cu}-\mathrm{Chit} / \mathrm{NC}_{\mathrm{S}}$ hydrogels) against $A$. flavus strains from animal feed samples is not previously studied. Present study aimed to: (1) recognize alfP and aflA as two essential genes that lead to development of aflatoxin in animal feed via Aspergillus genus. (2) determination of AFB1 and AFB2 frequency and distribution of A. flavus strains in relation to feed delivered to dairy cows in small farms. (3) copper-chitosan nanocomposite was produced utilizing metal vapor synthesis (MVS), the physicochemical characteristics of the nanocomposites formed were described by electron microscopy (TEM) transmission, $\mathrm{X}$-ray fluorescence analysis (XRF), and X-ray scattering (SAXS) small angle. (4) The fungicidal effect of the hydrogel $\mathrm{Cu}-\mathrm{Chit} / \mathrm{NCs}$ were screened against three $A$. flavus strains. (5) Protein, isozymes, and DNA fragmentations were investigated using two electrophoresis techniques, finally, scanning electron microscope was used to assess morphological changes in NCs-treated fungi.

\section{Materials and Methods}

\subsection{Chemicals and Reagents}

High-quality Acetone with a special purity $99.5 \%$ was used as a solvent for the production of metal nanoparticles via metal vapor synthesis (MVS) technique. Prior to the synthesis solvent, it was dried under molecular sieves $(4 \AA)$ and degassed in a vacuum pump under $10^{-1}$ Pa by freezing and thawing 
cycles. The metal source was $\mathrm{Cu}$ foil (99.99 percent) with a surface pre-treated with concentrated $\mathrm{HNO}_{3}$ and diluted $\mathrm{H}_{2} \mathrm{O}$ to remove oxide film.

In this work, two types of chitosan were used. Chitosan with a high molecular weight (ChitHMW) was purchased from ACROS Organics (Wheaton, IL, USA). Chitosan with a low molecular weight (ChitLMW) was bought from Wirud (Hamburg, Germany). Until impregnation, the chitosan powder was degassed at $40{ }^{\circ} \mathrm{C}$ for $12 \mathrm{~h}$ under a vacuum of $10^{-1} \mathrm{~Pa}$. Oxalic acid dihydrate was of analytical consistency.

\subsection{Preparation of Chitosan Powder Modified with $\mathrm{Cu} N \mathrm{NS}$}

Chitosan powder decorated with $\mathrm{Cu}$ NPs was prepared according to the procedure described in the previously published works [17-20]. For the preparation of organosol, $0.56 \mathrm{~g}$ of $\mathrm{Cu}$ foil (about $200 \mu \mathrm{m}$ of thickness) was resistively dispersed from the tantalum boat $(90 \mathrm{~mm} \times 5 \mathrm{~mm})$ and co-condensed with $160 \mathrm{~mL}$ of acetone on the liquid nitrogen-cooled walls of a quartz $5 \mathrm{~L}$ vessel. This procedure was carried out at a residual pressure of $10^{-5}$ within $1 \mathrm{~h}$. Then the cooling was removed and the reactor was filled with pure argon. Under these conditions, the cryomatrice warmed to room temperature naturally within $15 \mathrm{~min}$. As a result, the $\mathrm{Cu}$-acetone organosol was obtained. The calculated solvent-to-metal molar ratio in the synthesis was 250:1 and the concentration of the copper organosol was $510^{-2} \mathrm{M}$. $\mathrm{Cu}$-acetone organosol was then infiltrated with chitosan powder (HMW or LMW) in an evacuated Schlenk vessel. During the deposition procedure, the flask was stirred manually to obtain homogeneous material. Thereafter, the solvent was removed and the chitosan powder containing $\mathrm{Cu}$ NPs was dried in a vacuum of $10^{-1} \mathrm{~Pa}$ at $40^{\circ} \mathrm{C}$ for $6 \mathrm{~h}$. As a result, two types of powdered Cu-carrying composites based on ChitHMW and ChitLMW were prepared.

\subsection{Preparation of Chitosan Gels Modified with Cu NPs}

The following technique was used to prepare chitosan gels filled with $\mathrm{Cu}$ NPs. Cu-carrying chitosan powder $(1.32 \mathrm{~g}, 5$ percent $w / w)$ was dissolved in an oxalic acid solution $(25 \mathrm{~mL}, 1 \mathrm{M})$ with vigorous stirring at $80{ }^{\circ} \mathrm{C}$ for $30 \mathrm{~min}$. The mixture was poured into the cylindrical molds $(20 \mathrm{~mm} \times 10 \mathrm{~mm})$ and put in the water bath below $22^{\circ} \mathrm{C}$ to maintain a steady gel formation temperature. Each mold had $4 \mathrm{~g}$ of chitosan solution. After $12 \mathrm{~h}$, the prepared gels were soaked in a beaker filled with distilled water and cleaned thoroughly from excess acid until neutral $\mathrm{pH}$ was reached. With the methods described above, two types of gels were prepared:

$\mathrm{Cu} @$ ChitHMW—chitosan hydrogel doped with Cu NPs based on ChitHMW

$\mathrm{Cu} @$ ChitLMW—chitosan hydrogel doped with Cu NPs based on ChitLMW

For best solidification, chitosan gels were stored in a water/isopropanol $(6: 1, \mathrm{v} / \mathrm{v})$ bath at room temperature (RT).

\subsection{Characterization Techniques}

\subsubsection{Transmission Electron Microscope (TEM)}

TEM images were performed with a transmission electron microscope LEO 912AB OMEGA, Zeiss (Oberkochen, Germany) at an acceleration voltage of $100 \mathrm{kV}$. Cu-carrying chitosan composites for measurements were previously suspended in deionized water (resisting $18 \mathrm{M} \Omega$ ) and sonicated in an ultrasonic bath for $15 \mathrm{~min}$ at RT. Then, a small drop of the suspension was dripped onto a copper grid (200 mesh) previously coated with formvar film. Then, the samples were dried at RT for $15 \mathrm{~min}$ and placed under the microscope.

\subsubsection{X-Ray Fluorescence (XRF) Analysis}

To determine metal concentration $(\% w / w)$ in the composites, a VRA 30 X-Ray fluorescent analyzer (Leipzig, Germany) was used. To excite XF, an X-Ray tube with a Mo anode was used at the acceleration of $50 \mathrm{kV}$ and current of $20 \mu \mathrm{A}$. For analysis, Cu-chitosan powders or gels in an amount of 10-12 mg 
was thoroughly ground and pressed into pills. Then the XRF spectra of the composites and reference samples were recorded. The standard buffer solution for spectrometer calibration was composed of a mixture of polysterene/metal salt. Quantity analysis was conducted through comparison of the peak intensity of $\mathrm{Cu} \mathrm{K} \alpha$ line in XRF spectrum of the composite with the values of the calibration curve obtained previously.

\subsubsection{Conventional Small-Angle X-Ray Scattering (SAXS) Analysis}

SAXS measurements were done on laboratory diffractometer "AMUR-K" (developed in A. V. Shubnikov Institute of Crystallography, Moscow [21]). Wavelength of X-rays $\lambda=0.1542 \mathrm{~nm}$ was used, applying Kratky type geometry covered the range of scattering vector modulus $0.12<s<6.0 \mathrm{~nm}^{-1}$ $(s=4 \pi \sin \theta / \lambda ; 2 \theta$ is the scattering angle). Experimental data were normalized to the intensity of the incident beam, and then a correction on collimation error was made according to standard procedure [22]. Further data processing and interpretation was done using the program suit ATSAS [23].

Volume size distribution functions $D_{V}(R)$ of heterogeneities in the specimens and distance distribution functions $p(r)$ were computed by means of the regularization technique realized in program GNOM [24]. The low-resolution shapes of the $\mathrm{Cu}$ nanoparticles in the $\mathrm{Cu}$-carrying chitosan were reconstructed ab initio using distance distribution function $p(r)$ and program DAMMIN [25]. The program utilizes a simulated annealing algorithm to build models fitting the experimental data $I_{\text {exp }}(s)$ that minimizes the discrepancy:

$$
\chi^{2}=\frac{1}{N-1} \sum_{j}\left[\frac{I_{\exp }\left(s_{j}\right)-c I_{c a l c}\left(s_{j}\right)}{\sigma\left(s_{j}\right)}\right]^{2}
$$

where $N$ is the number of experimental points, $c$ is a scaling factor and $I_{\text {calc }}\left(s_{j}\right)$ and $\sigma\left(s_{j}\right)$ are the calculated intensity from the model and the experimental error on the intensities at the momentum transfer $s_{j}$, respectively. The program DAMMIN was run of about a dozen separate calculations to identify the most typical models.

\subsection{Aflatoxin-Producing Ability Medium}

Selected isolates from A. flavus (21 isolates) associated with dairy cattle feed samples collected from different governorates in Egypt were screened for aflatoxins production by four solid media. Four culture media recipes including A. flavus and parasiticus Agar (AFPA) (20 g/L yeast extract; $10 \mathrm{~g} / \mathrm{L}$ bacteriological peptone; $0.5 \mathrm{~g} / \mathrm{L}$ ferric ammonium citrate; and $15 \mathrm{~g} / \mathrm{L}$ agar) [26], coconut agar (CA), $\mathrm{PDA}+20 \% \mathrm{NaCl}$, and PDA were employed to confirm aflatoxins production. All tested media were equipped as described earlier by some mycologists [1,27]. Aflatoxins production was detected via UV fluorescent light, light brown circle closed to fungal colonies was appeared after one-week incubation at $28^{\circ} \mathrm{C}$.

\subsection{VICAM Aflatoxins Assay}

Culture broth filtrates of 21 aflatoxigenic Aspergilii collected from peanut cake and cotton seeds were analyzed for aflatoxins production (B1, B2, G1, and G2) (Figure 1) using AflaTest Immunoaffinity (VICAM) Chromatography assay that quantifies total aflatoxin concentrations according to the manufacturer's instructions. Briefly, $5 \mathrm{~mL}$ of diluted sample extract (2:3, extract:water) was filtered through the column with immunological properties with a drop per second. The column was cleaned with $10 \mathrm{~mL}$ of water by running two drops per second through the column. Aflatoxin was eluted by transferring $1 \mathrm{~mL}$ of methanol at one drop per second from the column. A volume of $1 \mathrm{~mL}$ of bromine developer was added to the methanol elute and the total aflatoxin concentration was read in a pre-calibrated VICAM Series-4 Fluorometer set at $360 \mathrm{~nm}$ absorption and $450 \mathrm{~nm}$ emissions with a detection limit of $2 \mathrm{ppb}(2 \mu \mathrm{g} / \mathrm{kg})$. Results for each sample were averaged and reported in ppb [28]. 

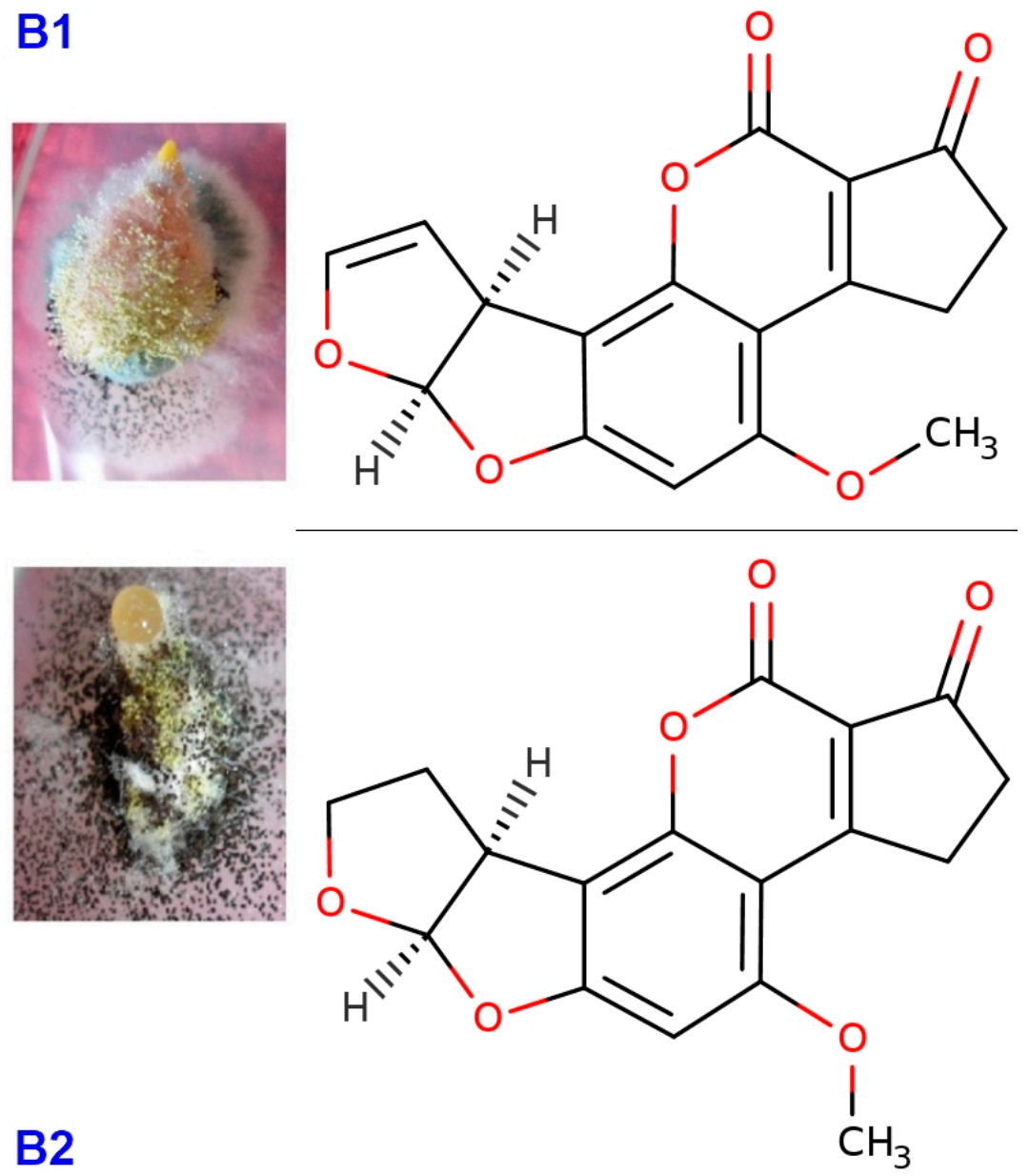

Figure 1. Structural formula of two type of aflatoxins produced by $A$. flavus isolated from peanut meal and cotton seed. Aflatoxin (B1) $\mathrm{C}_{17} \mathrm{H}_{12} \mathrm{O}_{6}(6 \mathrm{aR}, 9 \mathrm{aS})-4-M e t h o x y-2,3,6 \mathrm{a}, 9 \mathrm{a}-$ tetrahydrocyclopenta[c] furo[3', 2' :4,5]furo[2,3-h]chromen-1,11-dion. Aflatoxin (B2), $\mathrm{C}_{17} \mathrm{H}_{14} \mathrm{O}_{6}(6 \mathrm{aS}, 9 \mathrm{aR})-4-$ Methoxy-2,3,6a,8,9,9a hexahydrocyclopenta[c]furo[3', $\left.2^{\prime}: 4,5\right]$ furo[2,3-h]chromen-1,11-dion. Formula available online from: http://www.chemspider.com.

\subsection{DNA Extraction}

For the PCR amplification and DNA degradation assays, Aspergillus mycelium was grown in $20 \mathrm{~mL}$ of potato dextrose broth liquid medium ( $24 \mathrm{~g} / \mathrm{L}$ of potato dextrose broth (Difco Laboratories, Detroit, ML, USA)). Fungal mats were gathered by separation through mesh sieves ( $40 \mathrm{~mm}$ ), finally washed using sterile deionized, and dropped inside a Whatman filter paper to eliminate extra water. For homogenization, fungal mycelium was milled to acceptable powder in a mortar employing liquid nitrogen. The DNA protocol modified by Bahkali et al. [29] was used to obtain a highly purified DNA amplicon.

\subsection{PCR Assay for A. flavus Detection}

For specific detection of $A$. flavus, 64 PCR reaction contained $2 \mu \mathrm{L}$ of the extracted DNA and $23 \mu \mathrm{m}$ PCR mix containing $11.5 \mu \mathrm{L}$ Taq DNA polymerase (Jena, Germany), $5 \mathrm{mM}$ of two specific primers for $A$. flavus aflP (F-5'-CATGCTCCATCATGGTGACT-3'), (R-5' CCGCCGCTTTGATCTAGG-3') [30], aflA (F-5'-GGTGGT GAAGAAGTCTATCTAAGG-3'), and (R-5'AAGGCATAAAGGGTGTGGAG-3') [31]. PCR thermal cycler program was adjusted as follows: $7 \mathrm{~min}$ at $94^{\circ} \mathrm{C}$ tracked by 40 amplification cycles at $94{ }^{\circ} \mathrm{C}$ for $30 \mathrm{~s}$, annealing temperature 62 for $30 \mathrm{~s}, 72{ }^{\circ} \mathrm{C}$ for $30 \mathrm{~s}$, and then $72{ }^{\circ} \mathrm{C}$ for $3 \mathrm{~min}$ for the final extension. The amplified DNA was separated via $2 \%$ agarose gel electrophoresis containing ethidium 
bromide at $90 \mathrm{~V}$ for $30 \mathrm{~min}$. Agarose gel was detected in UV transilluminator light via Gel Documentation System (Uvitec, Cambridge, UK).

\subsection{Antifungal Assay}

To determine the inhibition of mycelial growth of $A$. flavus, four $\mathrm{Cu}$-Chit/NCs gel concentrations $(60,120,180$, and $240 \mathrm{ppm})$ were prepared as hydrogel discs for every disc containing $60 \mathrm{ppm}$. The anti-fungal efficacy of Ag-Chit-NCs was assessed by determining the reduction in fungal growth of A. flavus using agar-well diffusion assessment [32]. Each concentration of $\mathrm{Cu}-\mathrm{Chit} / \mathrm{NCs}$ gel has been applied to PDA plate, and petri dishes were inoculated with $A$. flavus fungal disks. Flavus isolates were incubated at $28^{\circ} \mathrm{C}$ for 10 days. The inhibition factor of growth was estimated and evaluated by the equation below. [33]. Growth Inhibition $($ percent $)=(R 1-R 2) / R 1 \times 100$ where $R 1$ was the control's radial growth and R2 for each therapy was the radial growth. After one week, the photographic record and the development of the radial colony was calculated. The experiments were conducted in three folds.

\subsection{Protein Profile Degradation Assay}

To investigate the $\mathrm{Cu}$-Chit/NCs gel mediated protein expression in A. flavus, SDS-PAGE analysis was performed by Laemmli method [34]. The extracted protein from the fungal mycelium was treated with $180 \mathrm{ppm}$ of $\mathrm{Cu}$-Chit/NCs gel concentrations and incubated for $8 \mathrm{~h}$. SDS-PAGE was performed using a $5-10 \%$ gradient of polyacrylamide gels containing $0.1 \%$ SDS. Proteins were investigated in $1.5 \mathrm{~mm}$ and $15 \mathrm{~cm}$ gels that work in dual vertical electrophoresis glass plates (Hoefer Scientific Instruments, San Francisco, CA, USA). Twenty microliters of the extracted protein were inoculated into polyacrylamide gels. SDS-PAGE samples were differentiated by separating the acrylamide gel at a stable electrical current of $30 \mathrm{~mA}$, and by using a separate gel at room temperature at $90 \mathrm{~mA}$, the gel was stained with silver staining. [34]. The typical molecular weight used for gel analysis was the Sigma protein marker, which is between $66,000,45,000$, and 22,000 $\mathrm{kDa}$.

\subsection{Native PAGE Isozyme Assay}

Fungal isozymes were purified by grinding $100 \mathrm{mg}$ of fungal mats in $1.0 \mathrm{~mL}$ extraction buffer (0.1 M Tris- $\mathrm{HCl}+2 \mathrm{mM}$ EDTA, $\mathrm{pH}$ 7.8). The extracted enzyme from fungal mats was treated with $180 \mathrm{ppm}$ of $\mathrm{Cu}$-Chit/NCs gel concentrations and incubated for $8 \mathrm{~h}$. Native-PAGE was used to separate two enzymatic activities under native conditions [35]. Electrophoretic technique were conducted with the electrode buffer Tris/Glycine ( $\mathrm{pH}$ 8.3) using 5 percent of the stacking gel and 6 percent of the separating gels. The $5 \mu \mathrm{L}$ enzyme samples were placed over each well of the stacking gel and the gel was initially run at $60 \mathrm{~V}$ replaced by $100 \mathrm{~V}$ later. After running native acrylamide gel, and for staining glucose 6-phosphate dehydrogenase (G6PD) (EC.1.1.1.49), native protein gel was incubated in a staining solution ( $0.1 \mathrm{mM}$ tris-HCL buffer, $\mathrm{pH} 8.8,7.5$ glucose 6-phosphate (di-sodium salt), $20 \mathrm{mg}$ NADP, $10 \mathrm{mg}$ MTT, $10 \mathrm{mg}$ PMS, $0.2 \mathrm{M} \mathrm{MgCl}_{2}$ ) in the dark at $37^{\circ} \mathrm{C}$ until dark blue band appear. To stop the reactions, the isozyme gel was washed and fixed in 50\% ethanol [36]. Peroxidase isozyme (EC 1.11. 1.7) was stained with incubated gels in a staining solution ( $50 \mathrm{mM}$ phosphate buffer, $\mathrm{pH} 5.0,50 \mathrm{mg}$ benzidine dihydrochloride, and $3 \%$ hydrogen peroxide), and the gel was washed in water and fixed in $50 \%$ glycerol [37].

\subsection{Binding/Degradation of Genomic Fungal DNA}

To check DNA quality, 10 microliters of $A$. flavus DNA were treated with $\mathrm{Cu}-\mathrm{Chit} / \mathrm{NCs}$ hydrogel $(180 \mathrm{ppm})$ for $2 \mathrm{~h}$ at $37^{\circ} \mathrm{C}$. The DNA amplicon treated NCs gel was separated on $1.5 \%(w / v)$ agarose gels prepared in $1 \times$ Tris-acetate-EDTA (TAE) and stained with ethidium bromide (EtBr, $10 \mathrm{mg} / \mathrm{mL}$ ). Five microliters of extracted and treated DNA from every pattern, along with $1 \mu \mathrm{L}$ DNA loading dye, become loaded into the wells. Agarose gel was run for $30 \mathrm{~min}$ at $90 \mathrm{~V}$ and visualized to check for DNA degradation inside the GelDoc (Uvitec, Cambridge, UK). 


\subsection{Scanning Electron Microscopy (SEM)}

Agar disks of A. flavus had been inserted into sterile cellophane films and transferred to PDA mixed with $180 \mathrm{ppm}$ of $\mathrm{Cu}-\mathrm{Chit} / \mathrm{NCs}$ hydrogel in Petri dishes, with one plugin keeping in the middle of the plate, and 3 replicates were used for every strain. The Petri dishes were incubated at $28{ }^{\circ} \mathrm{C}$ for 7 days. Cellophane coated with A. flavus was transferred and stuck in $2 \%(w / v)$ glutaraldehyde at $4{ }^{\circ} \mathrm{C}$ for $12 \mathrm{~h}$ in $0.1 \mathrm{M}$ phosphate buffer (PB; $\mathrm{pH} 7.0$ ). Aspergillus specimens will be put in the desiccator before further use. Upon drying, the samples prepared are assembled into the Poutron SEM coating system using standard double-sided adhesives with $\frac{1}{2}$ inch SEM nozzles and with a gold-palladium gold coating ( $60 \mathrm{~s}, 1.8 \mathrm{~mA}, 2.4 \mathrm{kV}$ ). All samples were tested with JEOL JXA-480 SEM (JEOL, Tokyo, Japan) at the National Research Center in Giza, Egypt.

\section{Results}

\subsection{Preparation and Characterization of $\mathrm{Cu}$-Carrying Chitosan Powders}

Chitosan modified with metal NPs was prepared in two steps. Firstly, Cu NPs were prepared by interaction of metal vapors with acetone vapors according to the MVS protocol (see experimental part). During the second step, freshly prepared $\mathrm{Cu}$-acetone organosol was deposited in situ onto chitosan powders. During the deposition procedure, the flask was stirred manually to obtain homogeneous material. Discoloration of organosol indicated the completeness of the nanoparticle's deposition on the biopolymer support and the color of powders changed from beige to dark-green. XRF analysis shows that the metal proportion of the Cu-carrying powders based on ChitLMW and ChitHMW is 0.5 and $0.83 \%$, respectively. Previously, the same method for preparing $\mathrm{Cu}$-carrying chitosan powders with a high copper concentration of 3-5\% w/w was used [20].

The TEM images in the bright field and the selected area diffraction pattern (SAED) for the newly prepared $\mathrm{Cu}$-acetone organosol have been seen in Figure 2A. As can be shown, SAED has diffuse reflexes suggesting the production of a significant number of very small particles. NPs have a mainly spherical shape and blurry boundaries. The NPs' sizes estimated from Figure 2B are in the range of $1<\mathrm{d}<4 \mathrm{~nm}$. The good solvating properties of acetone for preparing $\mathrm{Cu}$ NPs were shown in previously published works $[38,39]$.
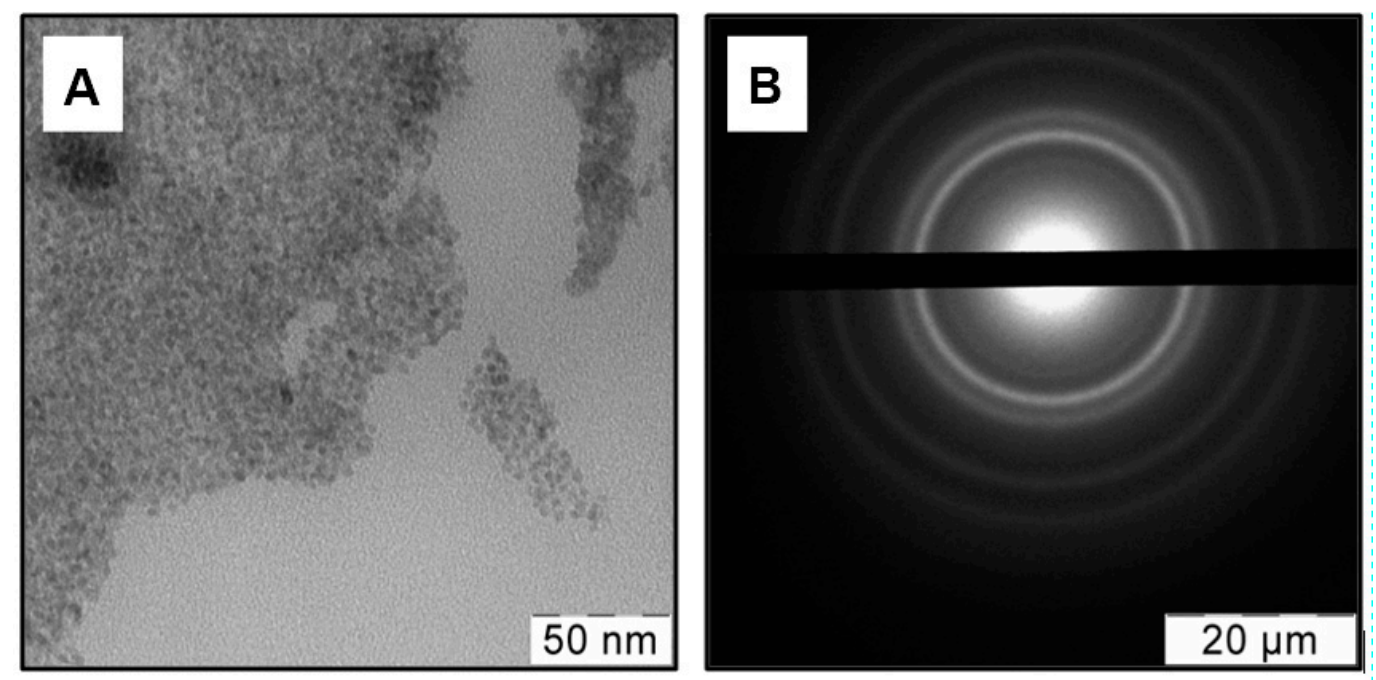

Figure 2. TEM image in bright field (A) and selected area diffraction pattern (SAED) (B) from a region for $\mathrm{Cu}$-acetone organosol.

Five rings correspond to the lattice planes of $\mathrm{Cu}$ and $\mathrm{Cu}_{2} \mathrm{O}$. As a result of the proximity of some interplanar distances of $\mathrm{Cu}$ and $\mathrm{Cu}_{2} \mathrm{O}$ and relatively broad rings, their superposition was observed. The formation of a core-shell structure of copper NPs with metallic copper as a core and copper oxide 
(I) as a shell can be assumed. A similar structure of $\mathrm{Cu}$ NPs in organosols prepared with different solvents via MVS was detected [40].

In Figure 3 TEM images in bright/dark field and SAED of powdered chitosan doped with Cu NPs using the impregnation step are shown. It was detected that $\mathrm{Cu}$-carrying chitosan composite contains $\mathrm{Cu}$ and $\mathrm{Cu}_{2} \mathrm{O}$ phases as well as $\mathrm{Cu}$-acetone organosol (Figure 3B). The crystallite sizes estimated from dark field image are in the range of $2-4 \mathrm{~nm}$ (Figure 3D).
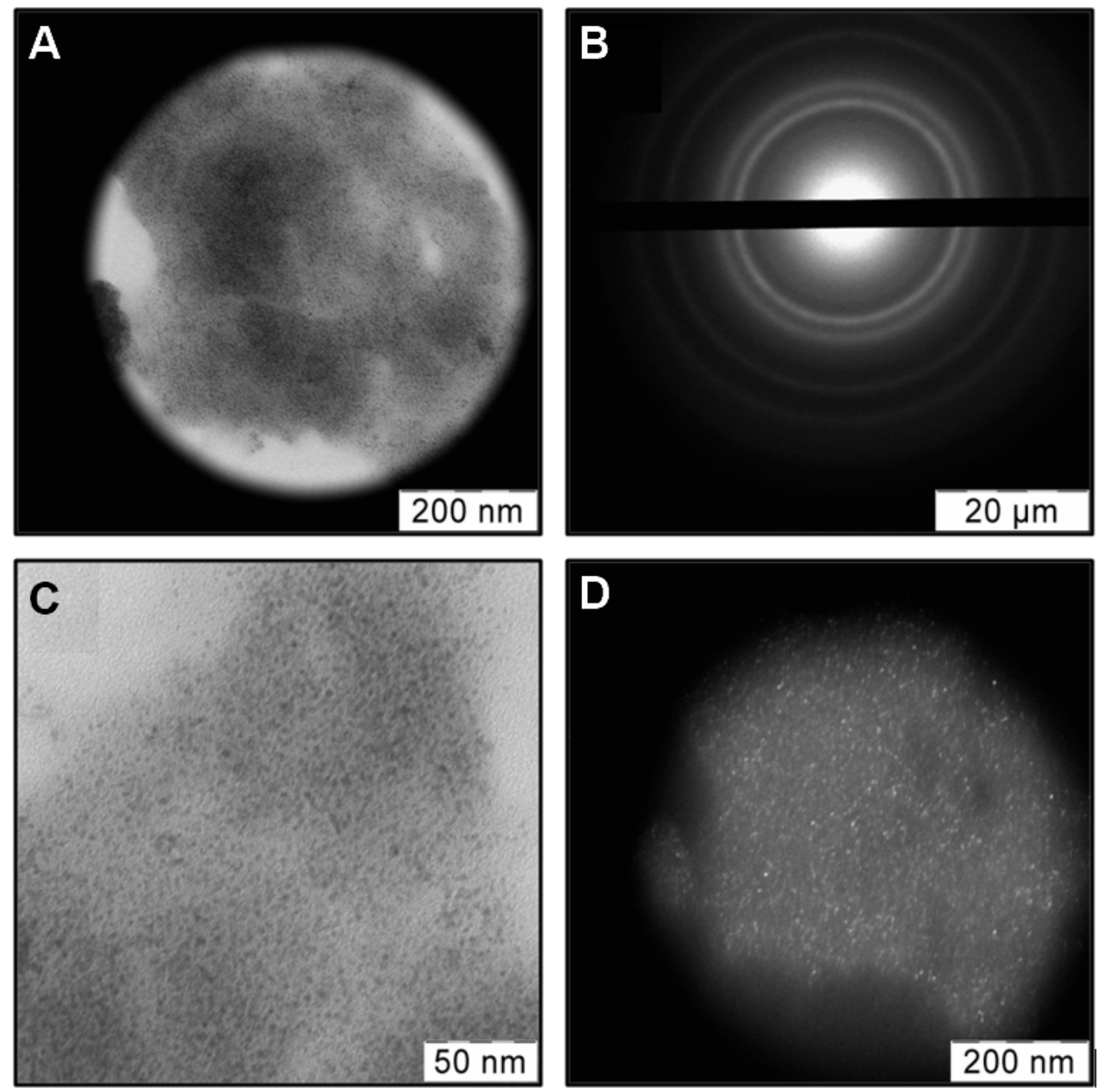

Figure 3. TEM images in bright $(A, C)$ and dark fields (D) of chitosan with a high molecular weight (ChitHMW) doped with copper nanoparticles (Cu NPs) as well as SAED (B) of highlighted field.

It was previously demonstrated that the surface of the composite prepared with $\mathrm{Cu}$-acetone organosol contains two oxidized copper states $\mathrm{Cu}^{2+}$ and $\mathrm{Cu}^{+}$, with concentrations (at. \%) of 10.7 and $3.6 \%$, respectively [20]. Experimental SAXS curves of Cu-carrying chitosan and pristine non-modified chitosan (ChitLMW) are described in Figure 4A.

Volume size distribution functions $D_{V}(R)$ of heterogeneities presented in pristine non-modified chitosan and that of $\mathrm{Cu}$ nanoparticles embedded in the chitosan are shown in Figure 4B. To obtain $D_{V}(R)$ only for the $\mathrm{Cu}$ nanoparticles, a difference SAXS curve was calculated by subtraction of the scattering of the pristine non-modified chitosan from the scattering of the Cu-carrying chitosan (Figure $4 \mathrm{~A}$ insert). As we can see from Figure 4B, Cu nanoparticles in this system are practically monodisperse and more compact (average size is about 1.5-2 $\mathrm{nm}$ ) to compare with the sizes of the pores of the pristine non-modified chitosan (about $3 \mathrm{~nm}$ ), where the $\mathrm{Cu}$ nanoparticles are located. A small detectable 
number of larger particles (possible aggregates or clusters of $\mathrm{Cu}$ nanoparticles) is also present in the sample. Due to the practically monodisperse character of the $D_{V}(R)$ function for $\mathrm{Cu}$ nanoparticles, one can reconstruct an average shape of the $\mathrm{Cu}$ nanoparticles [21]. For the ab initio restoration by the program DAMMIN [24], distance distribution function $p(\mathrm{r})$ was calculated. A shortened curve with no initial part at the range of momentum transfer $<0.7 \mathrm{~nm}^{-1}$ was used for the calculation to minimize the influence of scattering from large aggregates on the result of the shape restoration. The distance distribution function $p(r)$ is shown in Figure 5 (insert on the top right) along with a model scattering curve from a restored shape and with a smoothed curve after the of collimation corrections.
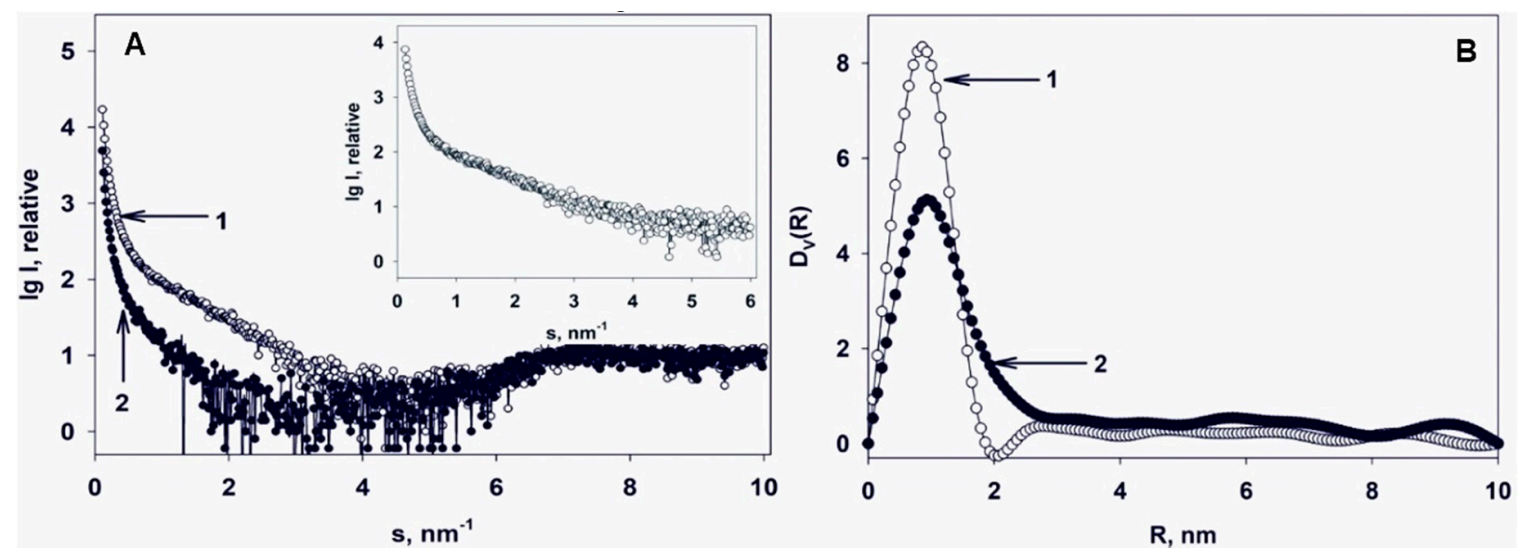

Figure 4. (A) Experimental (SAXS) curves: 1-Cu-carrying chitosan; 2-pristine non-modified chitosan (chitosan low molecular weight (ChitLMW)). Insert-difference SAXS curve for the embedded $\mathrm{Cu}$ nanoparticles. (B) Volume size distribution functions $D_{V}(R): 1-\mathrm{Cu}$ nanoparticles; 2-pristine non-modified chitosan (ChitLMW).

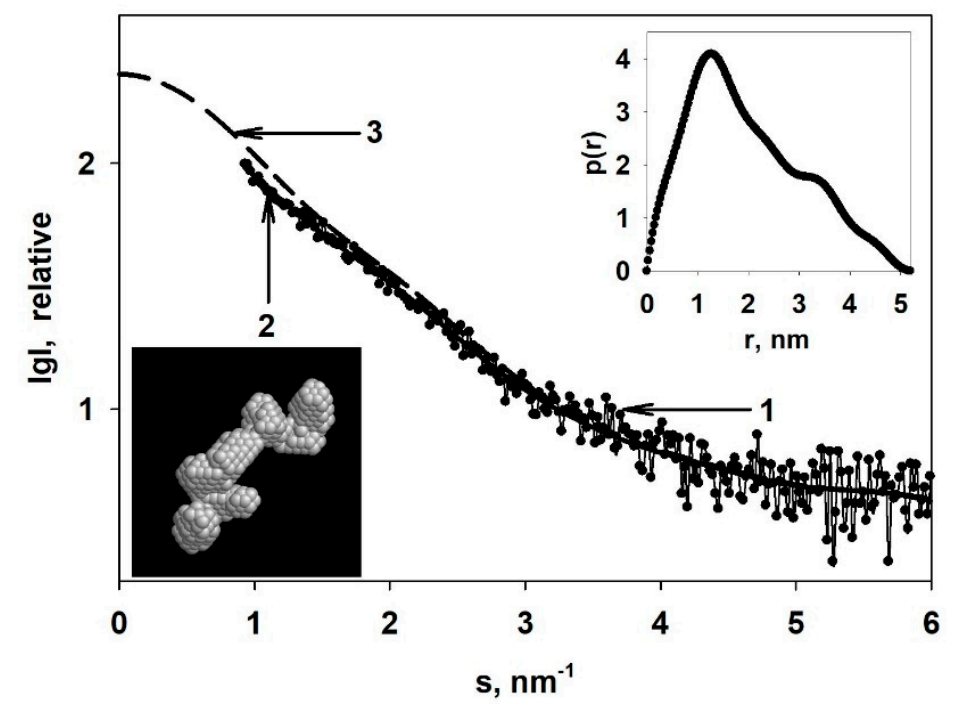

Figure 5. Reconstruction of the shape of the $\mathrm{Cu}$ nanoparticles in the $\mathrm{Cu}$-carrying chitosan: 1-difference SAXS curve; 2-a model scattering curve calculated from the restored shape of the Cu nanoparticles; 3-extrapolated to zero angles smoothed scattering curve after the introduction of collimation corrections. Inserts: top right-distance distribution function $p(r)$; bottom left-restored shape of the $\mathrm{Cu}$ nanoparticles.

The restored shape of the $\mathrm{Cu}$ nanoparticles is a cluster consisting of 5-6 individual $\mathrm{Cu}$ nanoparticles with the average sizes of about $1.5-2.0 \mathrm{~nm}$ and with the length of the cluster of about $5 \mathrm{~nm}$. Due to the presence of some amount of large aggregates it is impossible to restore the shape of the individual 
$\mathrm{Cu}$ nanoparticles. However, the shape of the cluster is restored with very good accuracy: $\chi^{2}=0.92$, and the separate nanoparticles in the cluster are clearly visible.

Chitosan gels have been produced by ionic physical gelation of the oxalic acid-biopolymer [41,42]. Two types of $\mathrm{Cu}$-carrying chitosan gels were obtained with the consecutive procedures of dissolution in oxalic acid at high temperature, gelation and thorough washing procedures (Figure 6).

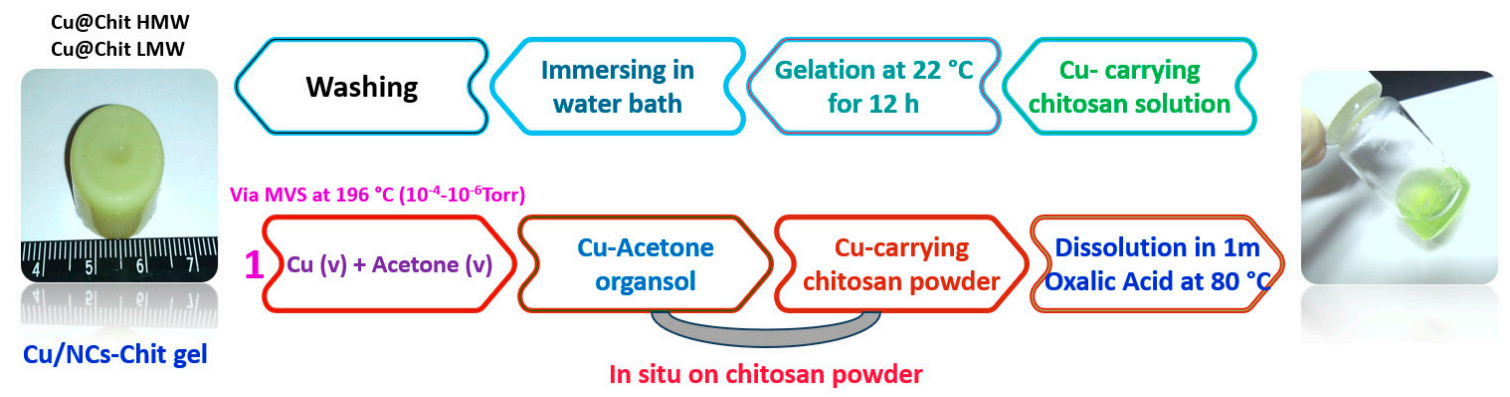

Figure 6. Scheme of preparation of chitosan hydrogels from $\mathrm{Cu}$-carrying chitosan powders.

\subsection{Aflatoxins Production Ability}

The production ability of toxigenic isolates was screened on four solid media. Beige rings seen without light are observed in aflatoxigenic fungal cultures. It is also possible to visualize the blue fluorescence ring that surrounds the aflatoxigenic colony under ultraviolet light. The aflatoxigenic A. flavus ${ }^{\circ} \mathrm{C}$. The detected beige ring diameter and the strength of its fluorescence emission were improved under UV over time with the maximum observation by the end of the week (Table 1). It is possible to use AFPA media that is suitable for fast screen aflatoxigenic fungi associated with feeds. Four forms of aflatoxin activity have been quantified and measured (B1, B2, G1, and G2). Production patterns of AFs by aflatoxigenic A. flavus isolates are presented in Table 1. Thirteen of these were producers of $\mathrm{AFB}_{1}$ and $\mathrm{AFB}_{2}$ aflatoxins and 8 were nonproducers of aflatoxins. Thirteen of the isolates produced aflatoxin B1 ranging from 4.50 to $19.44 \mathrm{ppb}$, while B2 was produced in the same isolates with a 0.02-5.29 ppb. A. flavus (Af1) produced the highest AFB1 concentration (19.44 ppb) while A. flavus (Af13) produced the intermediate quantity of AFB1 $(9.10 \mathrm{ppb})$ and Af13 produced the lowest quantity of AFB1 (4.50 ppb). None of the tested isolates produced aflatoxins G1 and G2.

Table 1. Fast screen aflatoxins by various cultural media and concentration of aflatoxins assayed by VICAM test in 21 Aspergillus flavus isolates collected from peanut meal and cottonseeds.

\begin{tabular}{|c|c|c|c|c|c|c|c|c|}
\hline \multirow{2}{*}{$\begin{array}{l}\text { Isolate } \\
\text { Code }\end{array}$} & \multirow{2}{*}{ Feed } & \multicolumn{4}{|c|}{$\begin{array}{c}\text { Fluorescence Detection under UV } \\
\text { Light }(365 \mathrm{~nm})\end{array}$} & \multicolumn{3}{|c|}{$\begin{array}{l}\text { The Concentration of Aflatoxins } \\
(\mathrm{ppb})\end{array}$} \\
\hline & & AFPA & CA & $\mathrm{PDA}+\mathrm{NaCl}$ & PDA & AFB1 & AFB2 & Total Aflatoxins \\
\hline Af1 & Peanut meal & + & - & + & - & 19.44 & 0.03 & 19.47 \\
\hline Af2 & Peanut meal & + & + & + & - & 13.54 & 0.02 & 13.56 \\
\hline Af3 & Peanut meal & + & + & - & - & 10.13 & 0.05 & 10.18 \\
\hline Af4 & Peanut meal & + & + & + & - & 14.22 & 5.29 & 19.51 \\
\hline Af5 & Peanut meal & + & - & - & - & 10.14 & 1.30 & 11.44 \\
\hline Af6 & Peanut meal & + & + & - & - & ND & ND & ND \\
\hline Af7 & Peanut meal & - & + & + & - & 12.10 & 3.20 & 15.30 \\
\hline Af8* & Peanut meal & + & + & + & - & 12.10 & 3.56 & 15.66 \\
\hline Af9 & Peanut meal & + & + & - & - & ND & ND & ND \\
\hline Af10 & Peanut meal & + & + & + & - & 10.13 & 0.05 & 10.18 \\
\hline
\end{tabular}


Table 1. Cont.

\begin{tabular}{lllllllll}
\hline \multirow{2}{*}{$\begin{array}{l}\text { Isolate } \\
\text { Code }\end{array}$} & \multirow{2}{*}{ Feed } & \multicolumn{3}{c}{$\begin{array}{c}\text { Fluorescence Detection under UV } \\
\text { Light }(\mathbf{3 6 5} \mathbf{~ n m})\end{array}$} & \multicolumn{3}{c}{ The Concentration of Aflatoxins } \\
(ppb)
\end{tabular}

\subsection{Aspergillus flavus PCR Detection}

A total of 21 Aspergillus flavus, and Aspergillus related isolates such as two isolates for both Aspergillus clavatus, Aspergillus ochraceous, Aspergillus niveus, Aspergillus terreus, Aspergillus fumigatus, Aspergillus versicolor, Penicillium paneum, Penicillium expansum, Penicillium citrinum, Penicillium verrucosum in addition to one isolate from Alternaria alternata were used for testing specificity of primers. Figure 7 indicates the findings of the PCR product inspection of the agarose gel assay; the presence of a band at $236 \mathrm{bp}$ for primers aflP and $412 \mathrm{bp}$ aflA primers, respectively and suggested the same predicted PCR product. The samples were prepared independently from individual strains, with an identical amount of DNA $(60 \mathrm{ng} / \mu \mathrm{L})$. Figure 7 shows the results for screening the specificity of the tested primers. Thus, two sets of primer pairs (aflP and aflA) are specific for the detection of $A$. flavus (Figure 7A,C). The results show that only A. flavus DNA can be amplified (lines 1 to 21), no PCR products from other Aspergillus species and Penicillium were obtained from lane 1 to 21 (Figure 7B). For rapid and accurate detection of A. flavus isolates tested in the current report, two PCR primer sets (aflP and aflA) were employed. The applicable primers amplified a PCR fragment sited near the 18SrRNA region with 95.3\% efficiency and $100 \%$ specificity. Ultimately, existing examinations suggest the powerful specificity of the aflA PCR primer over different typically available diagnostic primers for correct, speedy, and large-scale identification of $A$. flavus isolated from feeds. Most $A$. flavus strains were detected with the aid of specific-PCR by using the examined primer sets. 


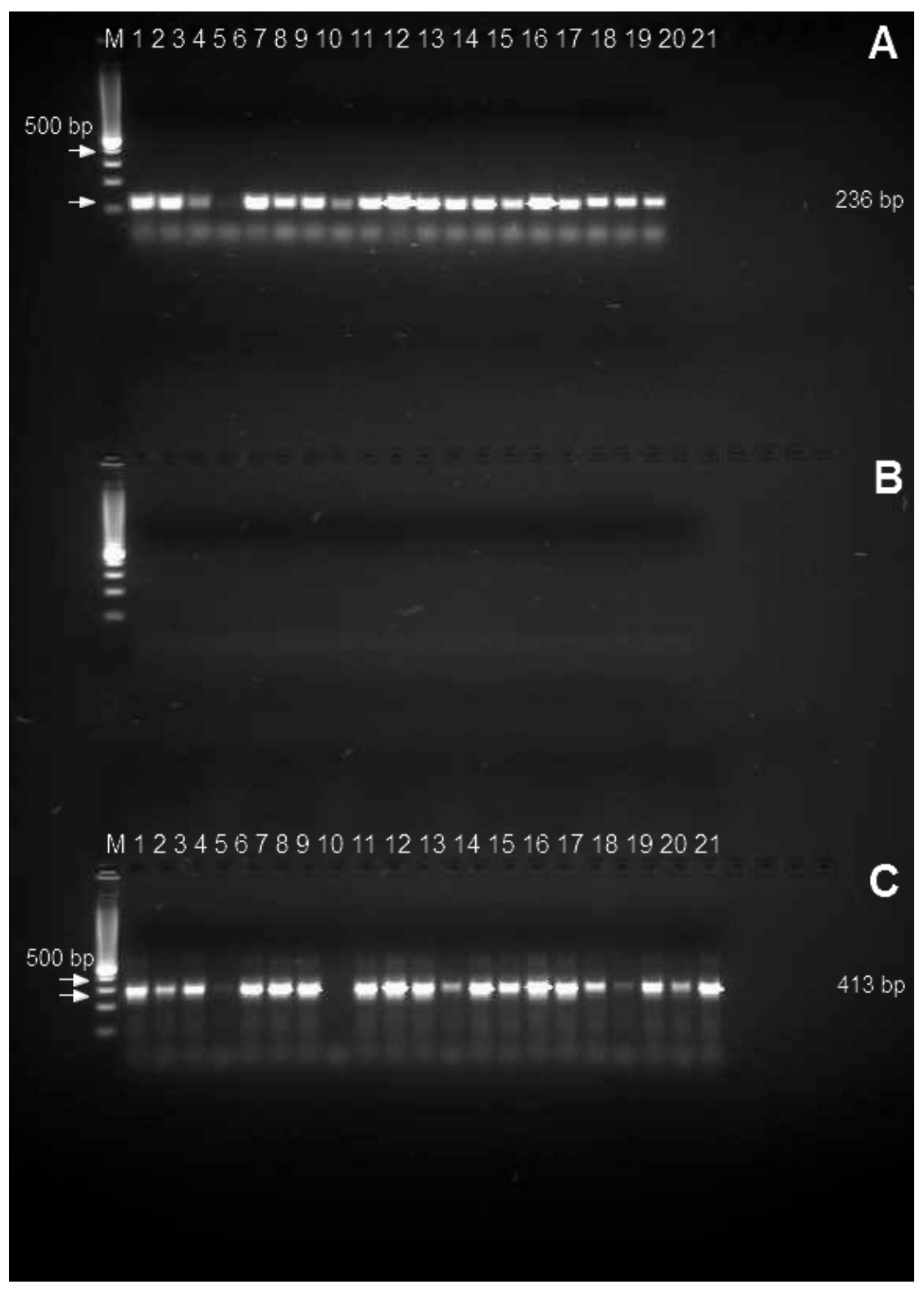

Figure 7. PCR amplicons obtained using primer pairs developed for the aflP (omtA) and aflA genes in 21 Aspergillus flavus (Lane1-21) tested with aflP primers (A), and an Aspergillus related isolate such as two isolates for both of Aspergillus clavatus, Aspergillus ochraceous, Aspergillus niveus, Aspergillus terreus, Aspergillus fumigatus, Aspergillus versicolor, Penicillium paneum, Penicillium expansum, Penicillium citrinum, Penicillium verrucosum and one Alternaria alternate isolate (Lane 1-21) tested with aflP primers (B). A total of 21 Aspergillus flavus (Lane1-21) tested with aflA primers (C).

\subsection{Antifungal Activity of NCs}

Various concentrations of $\mathrm{Cu}-\mathrm{Chit} / \mathrm{NCs}$ hydrogels were used to study the inactivation of A. flavus mycelia growth. The antifungal activity of the synthesized $\mathrm{Cu} / \mathrm{NCs}$ chit gel was assessed by measuring the radial growth of mycelium for all treatments (Figure 8). The highest mycelial growth inhibition was found at a concentration of $240 \mathrm{ppm}$ followed by 180,120, and $60 \mathrm{ppm}$ concentrations of $\mathrm{Cu}-\mathrm{Chit} / \mathrm{NCs}$ hydrogel. The antifungal activity of $\mathrm{Cu}-\mathrm{Chit} / \mathrm{NCs}$ hydrogel did not increase with increasing concentrations ranging between 60 and $120 \mathrm{ppm}$, while the inactivation rate constant increases with the concentration of $240 \mathrm{ppm}$ of the nanocomposite. The mycelial growth inhibition varies from $100 \%$ to $5.14 \%$ in different concentrations of prepared nanocomposites (Table 2). 


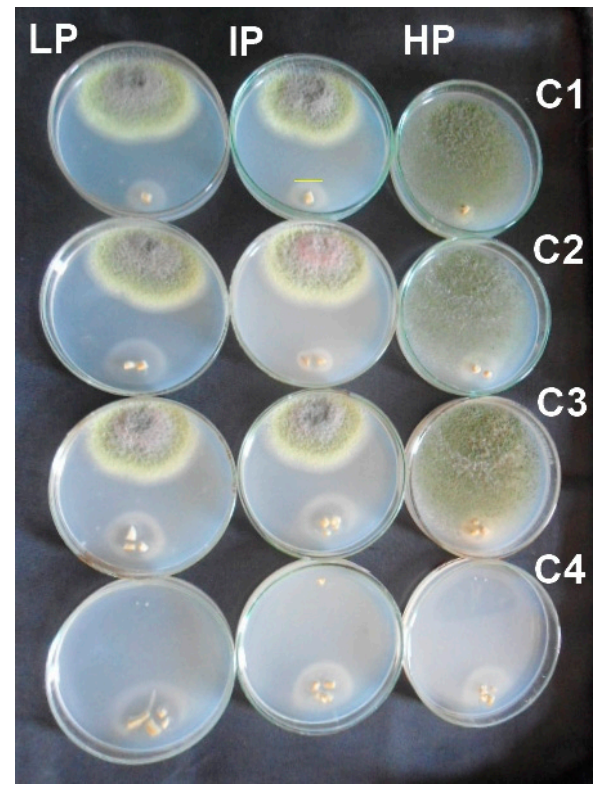

Figure 8. Antifungal activity for different concentration of $\mathrm{Cu}$-Chit/NCs gel $(\mathrm{C} 1=60, \mathrm{C} 2=120, \mathrm{C} 3=180$, and C4 $=240 \mathrm{ppm}$ ) against $A$. flavus isolated from feeds by the plate assay. All Petri dish treatments were incubated at $28^{\circ} \mathrm{C}$ for one week.

Table 2. Antifungal activity of $\mathrm{Cu}-\mathrm{Chit} / \mathrm{NCs}$ gel against three Aspergillus flavus strains.

\begin{tabular}{cccc}
\hline Serial Number & NCs Gel Concentrations (ppm) & Strain Code & \% Inhibition \\
\hline 1 & $\mathrm{C} 1=60$ & LP & 27.89 \\
\hline 2 & & IP & 28.66 \\
\hline 3 & $\mathrm{C} 2=120$ & HP & 5.14 \\
\hline 4 & & LP & 25.67 \\
\hline 5 & & IP & 28.43 \\
\hline 9 & $\mathrm{C} 3=180$ & HP & 6.48 \\
\hline 7 & & LP & 29.75 \\
\hline 8 & & IP & 29.20 \\
\hline 9 & & HP & 6.57 \\
\hline 10 & $\mathrm{C} 4=240$ & LP & 100 \\
\hline 11 & & IP & 100 \\
\hline 12 & & HP & 100 \\
\hline
\end{tabular}

\subsection{Protein and Isozymes Profile Degradation}

SDS-PAGE analysis was carried out to evaluate the change in gene expression of $A$. flavus handled with a hundred and eighty ppm of $\mathrm{Cu}-\mathrm{Chit} / \mathrm{NCs}$ gel. Some of the protein bands in the A. flavus isolates were not seen in the $\mathrm{Cu}-\mathrm{Chit} / \mathrm{NCs}$ gel treatment. In the control group, the protein pattern gave enhanced protein bands. In particular, there were 3 principal bands within the protein maker, inclusive of 66, 45, and $22 \mathrm{kDa}$, respectively. In high producer (HP) isolate from A. flavus treated with $180 \mathrm{ppm}$ of $\mathrm{Cu}-\mathrm{Chit} / \mathrm{NCs}$ gel, five bands completely disappeared with molecular weights of $12,17,26,38$, and $55 \mathrm{kDa}$, respectively. While in intermediate producer (IP) and low producer (LP), isolates were treated with the same concentration of nanocomposites, this resulted in the induction of three newly expressed proteins with approximate molecular weights of $10 \mathrm{kDa}, 32 \mathrm{kDa}$, and $40 \mathrm{kDa}$ (Figure 9A). Native-PAGE results observed that the activity of tested isozymes changed in the treated 
mycelium. For G6PD activity, six different banding patterns of enzymes appeared in untreated A. flavus isolates while enzyme activity in treated isolates with nanocomposites decreased to four isozymes (Figure 9B). Analysis of peroxidase isozymes revealed that from 4-6 peroxidase isozyme loci in both treated and untreated isolates. As a result, $\mathrm{Cu}$-Chit/NCs gels have no effect on peroxidase isozymes activity in fungal mats (Figure 9C). In the present report, we divide A. flavus isolates based on their aflatoxins ability into three types: high producer (HP), intermediate producer (IP), and low producer (LP). The same isolates were treated with $\mathrm{Cu}-\mathrm{Chit} / \mathrm{NCs}$ gel as a fellow $\mathrm{T} 1, \mathrm{~T} 2$, and $\mathrm{T} 3$, respectively.

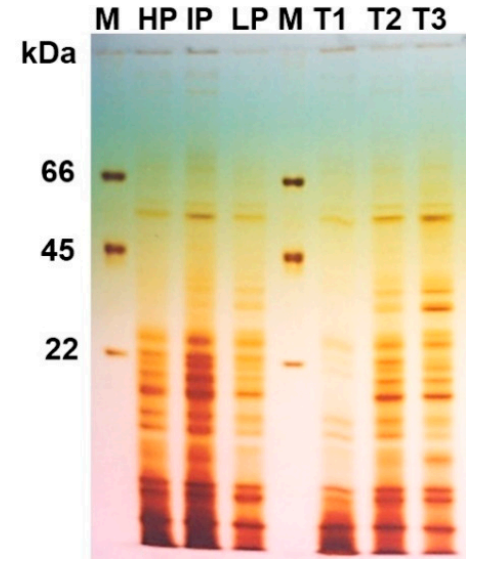

A

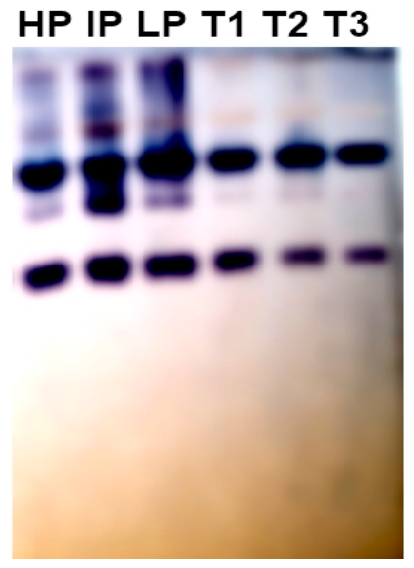

B

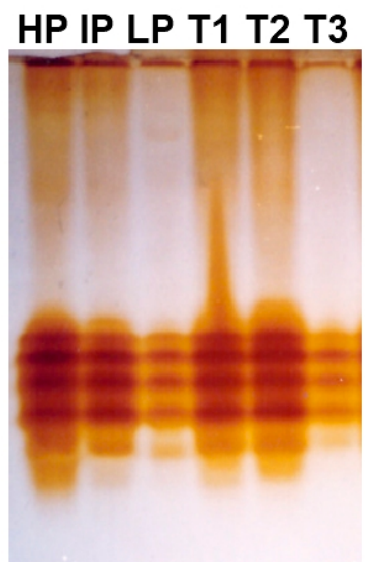

C

Figure 9. (A) Protein expression profile of SDS-PAGE extracted from A. flavus mycelium treated with a high $\mathrm{Cu}-\mathrm{Chit} / \mathrm{NCs}$ gel concentration. Lane $\mathrm{M}$ shows a standard protein molecular weight marker. Protein marker including three molecular bands ranging from 66, 45, and $22 \mathrm{kDa}$ was used. Isoenzymes electrophoresis of G6PD (B) and peroxidase (C) isozymes extracted from A. flavus mycelium treated with a high $\mathrm{Cu}-\mathrm{Chit} / \mathrm{NCs}$ gel concentration.

\subsection{DNA Binding and Degradation}

Separation of genomic DNA of fungi treated with $\mathrm{Cu}-\mathrm{Chit} / \mathrm{NC}$ gel by agarose electrophoresis is broken and DNA band are faint for selected samples, while no serious harm has occurred for untreated DNA. On the other side, the fungi treated with $180 \mathrm{ppm}$ of nanocomposites a slightly less intense band can be observed compared to the untreated sample (Figure 10). The genotoxic effects for fungal mycelium were investigated after treatment with $\mathrm{Cu}-\mathrm{Chit} / \mathrm{NCs}$ gel DNA degradations was separated especially at high concentrations of $\mathrm{Cu}-\mathrm{Chit} / \mathrm{NCs}$ gel.

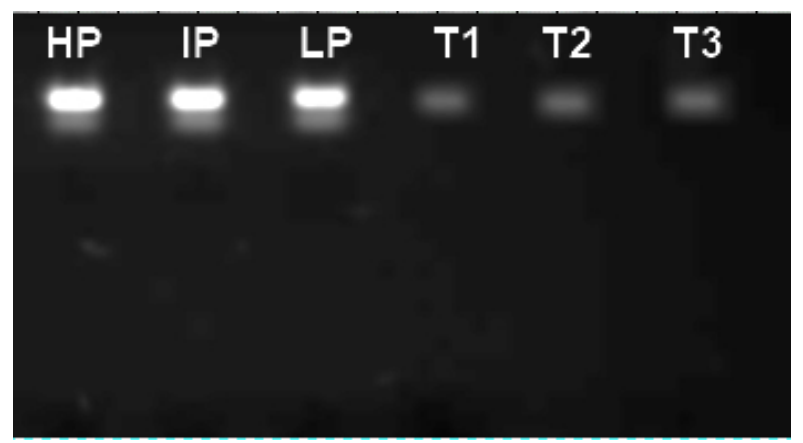

(A)

(B)

Figure 10. Agarose gel electrophoretic pattern of the fungal genomic DNA treated with $180 \mathrm{ppm}$ of Cu-Chit/NCs gel, (A) Lanes 1-3: DNA for untreated A. flavus isolates, Lane 1: A. flavus (high producer (HP) isolate), Lane 2: A. flavus (intermediate producer (IP) isolate), Lane 3: A. flavus (low producer (LP) isolate). (B) Lanes T1, T2, and T3, three A. flavus isolates DNA treated with Cu-Chit/NCs gel, showed total damage to fragmented DNA bands. 


\subsection{Fungal SEM}

Concerning the morphological structure of A. flavus investigated by SEM, adjustments in conidiophore attributes were watched. A. flavus was refined on PDA corrected with $180 \mathrm{ppm}$ of $\mathrm{Cu}-\mathrm{Chit} / \mathrm{NCs}$ hydrogel caused slight changes in mycelial structure, highlighted by hyphal twisting and by decreasing of regenerative structures, for example, conidia and conidiophores.

SEM investigation of conidiophore changes showed that fungal spores turned into glaringly extraordinary, in which mycelia and conidiophores were contracted in comparison to untreated controls (Figure 11). Alterations of hyphae structure have been determined as proven in Figure 11A-C along with lower of cytoplasmic content material and adjustments of membrane integrity. whilst, in untreated control, development of mycelium and conidiophore was regular with considerable conidia (Figure 11D-F).

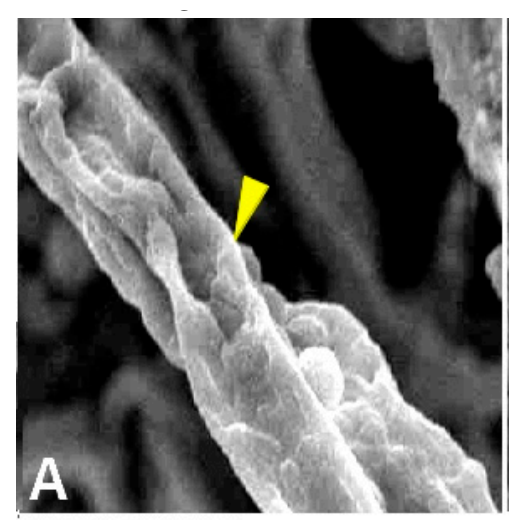

$\mathrm{X} 550,20 \mu \mathrm{m}$

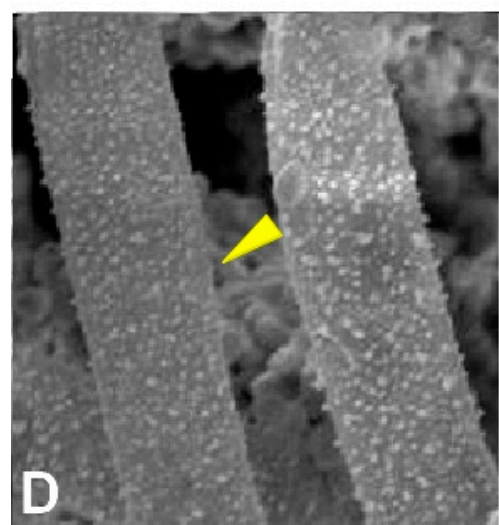

$\mathrm{X} 550,20 \mu \mathrm{m}$

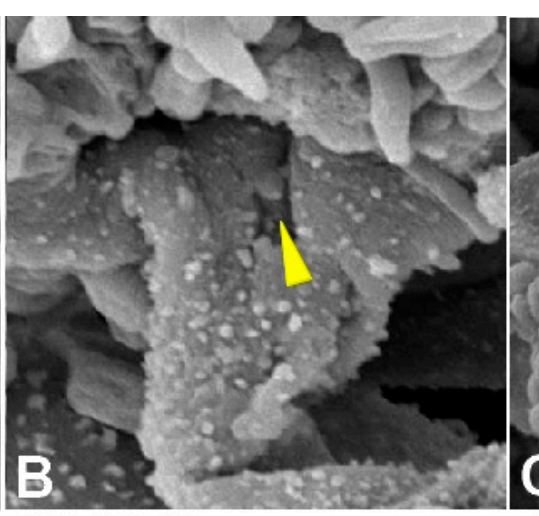

$\mathrm{X} 1700,10 \mu \mathrm{m}$

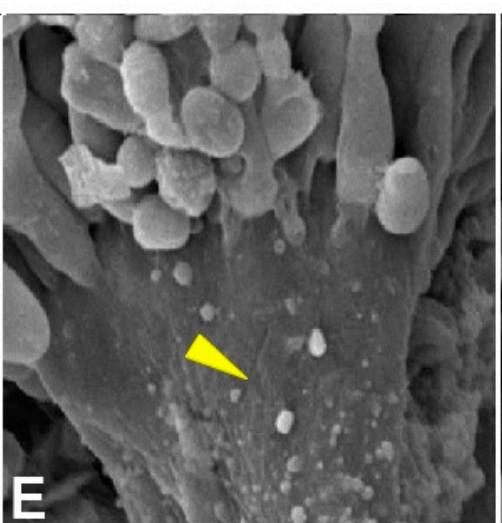

$\mathrm{X} 1500,10 \mu \mathrm{m}$

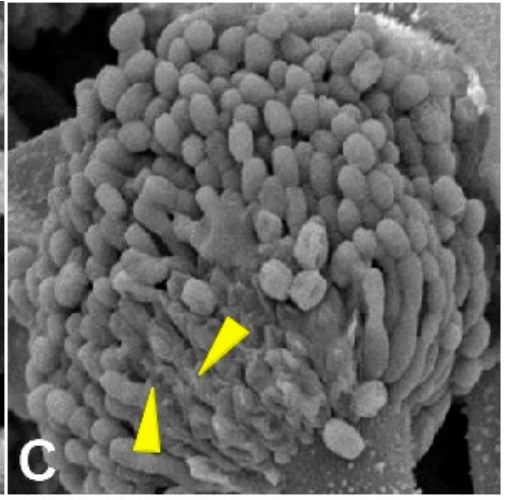

$\mathrm{X} 800,20 \mu \mathrm{m}$

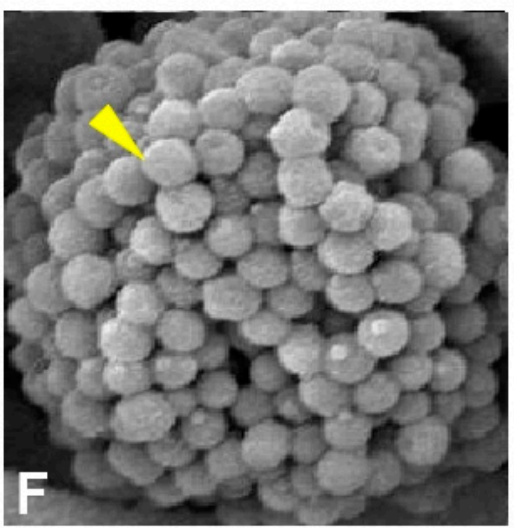

$\mathrm{X} 800,20 \mu \mathrm{m}$

Figure 11. Scanning electron micrographs showing shriveled conidiophores $(\mathbf{A}-\mathbf{C})$ and the healthy mycelium or conidiophores (D-F) of A. flavus on PDA treated with $\mathrm{Cu}-\mathrm{Chit} / \mathrm{NCs}$ hydrogel. The yellow arrows mean hyphae or conidiophore.

\section{Discussion}

There is an enormous interest to expand effective and eco-friendly fungicides anti-toxigenic fungi with low level or zero mycotoxin residues without affecting the plant growth and crop productivity of the essential agriculture ingredients [9]. The primary target of the current examination is to evaluate the antifungal impacts of bio-polymers like chitosan cross breed with copper metals against $A$. flavus aflatoxin-creating strains. Measures of aflatoxin formed in cultural media show some alarms on the toxigenic capability of various fungal isolates to deliver a high quantity of aflatoxin in agricultural supplies [43]. In the present work, analysis of aflatoxin-producing ability by fluorescence in CA an AFPA medium showed a good correlation with the biochemical examination of aflatoxins, a cutting-edge finding in a harmony with Monda et al. [44]. However, for most purposes, we found the CA media screening technique to be simpler, faster, and much cheaper than any of the different techniques 
examined [45]. Although the data indicate that the aflatoxins distinguished producer media such as AFPA is not completely persistent in differentiating between aflatoxin-producing and nontoxigenic strains of $A$. flavus, it is important that the fungal medium did not yield false-positives [46].

Our results show that $62 \%$ percent of $A$. flavus is aflatoxin-producing isolates. Fifty percent of the screened isolates of $A$. flavus collected from discolored rice grains in India can produce aflatoxin B1 [47]. These results are in agreement with Abbas et al. [48] who investigated more noteworthy producer A. flavus strains. Lai et al. [49] indicated that more than $35 \%$ of A. flavus strains secreted various quantities of aflatoxins in the rice grain. The diverse aflatoxin production capacities of the A. flavus isolates would be affected by the various resources of the strains and also ecological problems. The aflatoxin production pathway includes roughly 30 genes, some having unsure functions in aflatoxin biosynthesis [50].

In the present work, A. flavus isolates were tested for the presence of gene alf $A$, which is code for fatty acid synthases, while structural gene aflP is one of the main genes responsible for transforming ST into O-methylsterigmatocystin [51]. Our findings show that the two primers sets are specific for fast detection of $A$. flavus. Based on specific target genes such as afl $A$ and aflP, the present findings confirmed the applicability of PCR assays for the detection of A. flavus isolated from the feeds. Researchers reported strong antifungal activity of $\mathrm{Cu}$ NPs and chitosan nanocomposites against $A$. flavus, for example, benzoic acid nanogel (CS-BA) [10], CuO NPs [12], nanocomposites anti-aflatoxigenic $[3,5,13,14]$. In the current work, $\mathrm{Cu}-\mathrm{Chit} / \mathrm{NC}_{\mathrm{S}}$ hydrogel showed complete inhibition of growth against $A$. flavus strains at the highest concentration (240 ppm). Furthermore, we reported that the antifungal efficacy is influenced not only by nanocomposites concentration but also by type of tested strain. The antifungal efficacy of copper oxide nanoflowers as an antifungal agent against some phytopathogenic fungi like, $A$. niger, A. flavus, Penicillium notatum, and A. alternata were reported [52]. In addition, CS-Cu and CSZn NCPs show strong in vitro antifungal activity against A. alternata, Rhizoctonia solani, and A. flavus and are introduced as potential materials for innovative antimicrobials in cosmetics, foodstuffs, and textiles [53]. In in vitro assays, $\mathrm{Cu}$-chitosan NPs were found to be effective in inhibiting fungal growth of some plant pathogens such as Alternaria solani and Fusarium oxysporum [54]. The antifungal activity of CS NPs against two aflatoxin producers such as A. flavus and A. parasiticus was demonstrated [55] and CS NPs succeeded in reducing total aflatoxin production and inhibiting the extent of fungal growth. The main protein composition in the absence or presence of $\mathrm{Cu}-\mathrm{Chit} / \mathrm{NCs}$ gel was analyzed by SDS-PAGE in comparison with protein markers and depending on the amino acid composition. Many protein bands have not been seen in nanocomposite treatment. Subsequently, the treatment of chitosan nanocomposites generates some biological reactions, such as oxidative stress-induced metabolic changes, which in turn affect the protein synthesis rate [56]. The toxicity of nanocomposites in fungal cells is due to severe metabolic changes, in particular protein synthesis, which resulted in a maximum protein reduction, as verified by the absence of the most important protein synthesis [57].

G6PD is a housekeeping enzyme that primarily regenerates adenine dinucleotide phosphate (NADPH) nicotinamide to sustain cellular redox homeostasis. Since NADPH is necessary for NADPH oxidase (NOX), synthase of nitrogen oxides to generate reactive oxygen species, and for signaling nitrogen, several new cellular functions have been established for G6PD [58]. Lack of glucose-6-phosphate dehydrogenase isozyme can make nanoparticles more susceptible to oxidative stress [59]. Several experiments can be checked that they explain the impact of metals on G6PDH activity, also $\mathrm{Cd}^{++}$greatly influences on G6PDH activity in bacteria, fungi, and vertebrates; $\mathrm{Ni}^{++}$inhibits the enzyme 's kinetic properties in mammals; $\mathrm{Zn}^{++}$has extreme effects from a variety of influences on $\mathrm{G} 6 \mathrm{PDH} ; \mathrm{Cu}^{++}$has severe effects from bacteria and animals on G6PDH [60].

G6PD stimulates xenobiotic metabolism via the Nof2 signaling pathway and impacts the xenobiotic-metabolizing expression of the enzyme [61]. The full sense is that the inhibition of A. aculeatus G6PD activity by zinc and many other metal nanoparticles may be reinforced by potential production or otherwise formulation of polyketide mycotoxins in toxigenic fungi, including Aspergillus [62]. Additional attempts and modes of action study are needed to examine the molecular mechanisms 
on which G6PD interacts with the Nrf2 pathway. This is the first report showing G6PD isozymes activity in A. flavus strains treated with prepared nanocomposites to understand the antifungal mechanisms. SEM images of the treated pathogen above show that the hyphae also had a swollen appearance, damaging the plasma membrane of both fungal spores and mycelium. Similar outcomes were investigated by Rubina et al. [20], who discovered that Cu-chitosan nanocomposites deteriorate fungal mycelia of $R$. solani from cotton and also S. rolfsii pathogenic to onion. Gold nanoparticles may alter and disturb the fungal cell membranes of A. flavus, F. verticillioides, and P. citrinumdue [63]. Weak sporulation with shrinking spores and defects was found in all A. versicolor strains treated with the modified nanocomposites [64]. More omics tools such as functional genomics, transcriptomics, proteomics, and metabolomics are required for the identification of different antifungal mechanism pathways for various nanomaterials that can be used against aflatoxigenic strains of Aspergillus and also suppress their aflatoxins production.

\section{Conclusions}

Dairy cattle feed is prone to fungal infections and major fungus infecting peanut meals, and cotton seeds are A. flavus with aflatoxins producing nature. Therefore, an urgent need to produce novel and safer nano-biocides to prevent fungal contamination of food and feed. Current research shows that these two media can only distinguish between aflatoxigenic and non-aflatoxigenic isolates from A. flavus. Most $A$. flavus strains react positively with aflP primers and aflA covering regions $236 \mathrm{bp}$ and $412 \mathrm{bp}$, respectively. Current results suggest that the prepared nanocomposites hydrogel could be used not only as an effective fungicide against plant pathogens but also can be effectively used for the management of toxigenic fungi. In addition, omics technologies can be extended to improve our knowledge of toxigenic fungi, classify fungal species, predict fungal contamination, and may also facilitate the progress of plant breeding by gene insertion technologies to improve host plant tolerance, deter or minimize contamination of mycotoxins in feed. In addition, omics technologies can be extended to improve our knowledge of toxigenic fungi, classify fungal species, predict fungal contamination, and may also facilitate the progress of plant breeding by nanobiotechnologies to improve host plant tolerance, deter, or minimize contamination of mycotoxins in feed.

Author Contributions: K.A.A.-E., project administration, resources, conceptualization; M.A.A., biology methodology; A.S., methodology, data analysis, resources; M.S.R., nanomaterials synthesis; S.S.A. and E.V.S., material characterizations; A.Y.V., methodology, validation; K.A.A.-E., A.S., M.S.R., S.S.A., E.V.S., A.Y.V., writing-review and editing, supervision. All authors have read and agreed to the published version of the manuscript.

Funding: Current research was supported by the Science and Technology Development Fund (STDF), Joint Egypt (STDF)-South Africa (NRF) Scientific Cooperation, Grant ID. 27837 to Kamel Abd-Elsalam.

Acknowledgments: The authors would like to thank Ministry of Science and Higher Education of the Russian Federation for Physicochemical characterizations of copper-chitosan nanocomposite.

Conflicts of Interest: The authors declare no conflict of interest. The funders had a main role in the design of the study; in the collection, analyses, or interpretation of data; in the writing of the manuscript, or in the decision to publish the results.

\section{References}

1. Almoammar, H.; Bahkali, A.H.; Abd-Elsalam, K.A. A Polyphasic method for the identification of aflatoxigenic'aspergillus' species isolated from camel feeds. Aust. J. Crop. Sci. 2013, 7, 1707.

2. Omeiza, G.K.; Kabir, J.; Kwaga, J.K.P.; Kwanashie, C.N.; Mwanza, M.; Ngoma, L. A Risk assessment study of the occurrence and distribution of aflatoxigenic Aspergillus flavus and Aflatoxin B1 in dairy cattle feeds in a Central Northern State, Nigeria. Toxicol. Rep. 2018, 5, 846-856. [CrossRef]

3. Li, Z.; Lin, S.; An, S.; Liu, L.; Hu, Y.; Wan, L. Preparation, characterization and Anti-Aflatoxigenic activity of chitosan packaging films incorporated with turmeric essential oil. Int. J. Biol. Macromol. 2019, 131, 420-434. [CrossRef] [PubMed] 
4. Mateo, E.M.; Gómez, J.V.; Domínguez, I.; Gimeno-Adelantado, J.V.; Mateo-Castro, R.; Gavara, R.; Jiménez, M. Impact of bioactive packaging systems based on EVOH films and essential oils in the control of aflatoxigenic fungi and aflatoxin production In Maize. Int. J. Food Microbiol. 2017, 254, 36-46. [CrossRef]

5. Kumar, A.; Singh, P.P.; Prakash, B. Unravelling the antifungal and Anti-Aflatoxin B1 Mechanism of Chitosan Nanocomposite Incorporated with Foeniculum vulgare essential oil. Carbohydr. Polym. 2020, 236, 116050. [CrossRef] [PubMed]

6. Loeffler, S.H.; de Vries, M.J.; Schukken, Y.H. The effects of time of disease occurrence, milk yield, and body condition on fertility of dairy cows. J. Dairy Sci. 1999, 82, 2589-2604. [CrossRef]

7. Abd-Elsalam, K.A.; Hashim, A.; Alghuthaymi, M.A.; Bahkali, A.H. Nanobiotechnological strategies for molud and mycotoxin control. In Nanotechnology in Food Industry, Volume VI: Food Preservation; Grumezescu, A.M., Ed.; ELSEVIER: Amsterdam, The Netherlands, 2016; pp. 337-364.

8. Horky, P.; Skalickova, S.; Baholet, D.; Skladanka, J. Nanoparticles as a solution for eliminating the risk of mycotoxins. Nanomaterials 2018, 8, 727. [CrossRef] [PubMed]

9. Rai, M.; Abd-Elsalam, K.A. Nanomycotoxicology Treating Mycotoxins in Nano Way, 1st ed.; Academic Press: Amsterdam, The Netherlands, 2019; p. 450. Available online: https://www.elsevier.com/books/ nanomycotoxicology/rai/978-0-12-817998-7 (accessed on 19 April 2020).

10. Khalili, S.T.; Mohsenifar, A.; Beyki, M.; Zhaveh, S.; Rahmani-Cherati, T.; Abdollahi, A.; Bayat, M.; Tabatabaei, M. Encapsulation of Thyme Essential Oils In Chitosan-Benzoic Acid Nanogel with Enhanced Antimicrobial Activity Against Aspergillus flavus. LWT-Food Sci. Technol. 2015, 60, 502-508. [CrossRef]

11. Bocate, K.P.; Reis, G.F.; de Souza, P.C.; Junior, A.G.O.; Durán, N.; Nakazato, G.; Furlaneto, M.C.; de Almeida, R.S.; Panagio, L.A. Antifungal Activity of silver nanoparticles and simvastatin against toxigenic species of Aspergillus. Int. J. Food Microbiol. 2019, 291, 79-86. [CrossRef]

12. Devipriya, D.; Roopan, S.M. Cissus quadrangularis Mediated Ecofriendly Synthesis of Copper Oxide Nanoparticles and its Antifungal Studies Against Aspergillus niger, Aspergillus flavus. Mater. Sci. Eng. C 2017, 80, 38-44. [CrossRef]

13. Jampílek, J.; Králová, K. Nanocomposites: Synergistic nanotools for management of mycotoxigenic Fungi. In Nanomycotoxicology; Academic Press: Amsterdam, The Netherlands, 2020; pp. 349-383.

14. Tamayo, L.; Azócar, M.; Kogan, M.; Riveros, A.; Páez, M. Copper-Polymer nanocomposites: An excellent and cost-effective biocide for use on antibacterial surfaces. Mater. Sci. Eng. C 2016, 69, 1391-1409. [CrossRef]

15. Hossain, F.; Follett, P.; Salmieri, S.; Vu, K.D.; Fraschini, C.; Lacroix, M. Antifungal activities of combined treatments of irradiation and Essential Oils (Eos) Encapsulated chitosan nanocomposite films In Vitro and In Situ conditions. Int. J. Food Microbiol. 2019, 295, 33-40. [CrossRef] [PubMed]

16. Xiong, J.L.; Wang, Y.M.; Nennich, T.D.; Li, Y.; Liu, J.X. Transfer of dietary Aflatoxin B1 to Milk aflatoxin M1 and effect of inclusion of adsorbent in the diet of dairy cows. J. Dairy Sci. 2015, 98, 2545-2554. [CrossRef] [PubMed]

17. Vasil'kov, A.Y.; Rubina, M.S.; Naumkin, A.V.; Zubavichus, Y.V.; Belyakova, O.A.; Maksimov, Y.V.; Imshennik, V.K. Metal-Containing systems based on chitosan and a Collagen-Chitosan composite. Russ. Chem. Bull. 2015, 64, 1663-1670. [CrossRef]

18. Vasil'kov, A.Y.; Rubina, M.S.; Gallyamova, A.A.; Naumkin, A.V.; Buzin, M.I.; Murav'eva, G.P. Mesoporic material from microcrystalline cellulose with gold Nanoparticles: A new approach to metal-carrying polysaccharides. Mendeleev Commun. 2015, 25, 358-360. [CrossRef]

19. Rubina, M.S.; Kamitov, E.E.; Zubavichus, Y.V.; Peters, G.S.; Naumkin, A.V.; Suzer, S.; Vasil'kov, A.Y. Collagen-Chitosan scaffold modified with Au and Ag nanoparticles: Synthesis and structure. Appl. Surf. Sci. 2016, 366, 365-371. [CrossRef]

20. Rubina, M.S.; Vasil'kov, A.Y.; Naumkin, A.V.; Shtykova, E.V.; Abramchuk, S.S.; Alghuthaymi, M.A.; Abd-Elsalam, K.A. Synthesis and characterization of chitosan-copper nanocomposites and their fungicidal activity against two sclerotia-forming plant pathogenic Fungi. J. Nanostructures Chem. 2017, 7, $249-258$. [CrossRef]

21. Mogilevskiy, L.Y.; Dembo, A.T.; Svergun, D.I.; Feygin, L.A. Small-angle X-ray diffractometer with single coordinate detector. Crystallography 1984, 29, 587-591.

22. Feigin, L.A.; Svergun, D.I. Structure Analysis by Small-Angle X-ray and Neutron Scattering; Plenum Press: New York, NY, USA, 1987. 
23. Franke, D.; Petoukhov, M.V.; Konarev, P.V.; Panjkovich, A.; Tuukkanen, A.; Mertens, H.D.T.; Kikhney, A.G.; Hajizadeh, N.R.; Franklin, J.M.; Jeffries, C.M.; et al. ATSAS 2.8: A Comprehensive Data Analysis Suite for small-angle scattering from macromolecular solutions. J. Appl. Crystallogr. 2017, 50, 1212-1225. [CrossRef]

24. Svergun, D.I. Determination of the regularization parameter in indirect-transform methods using perceptual criteria. J. Appl. Crystallogr. 1992, 25, 495-503. [CrossRef]

25. Svergun, D.I. Restoring low resolution structure of biological macromolecules from solution scattering using simulated annealing. Biophys. J. 1999, 76, 2879-2886. [CrossRef]

26. Pitt, J.I.; Hocking, A.D.; Glenn, D.R. An improved medium for the detection of Aspergillus flavus and A. parasiticus. J. Appl. Bacteriol. 1983, 54, 109-114. [CrossRef] [PubMed]

27. Samson, R.A.; Visagie, C.M.; Houbraken, J.; Hong, S.B.; Hubka, V.; Klaassen, C.H.; Perrone, G.; Seifert, K.A.; Susca, A.; Tanney, J.B.; et al. Phylogeny, identification and nomenclature of the genus aspergillus. Stud. Mycol. 2014, 78, 141-173. [CrossRef] [PubMed]

28. Kaaya, A.N.; Eboku, D. Mould and aflatoxin contamination of dried cassava chips in eastern uganda: Association with traditional processing and storage practices. J. Biol. Sci. 2010, 10, 718-729. [CrossRef]

29. Bahkali, A.H.; Abd-Elsalam, K.A.; Guo, J.R.; Khiyami, M.A.; Verreet, J.A. Characterization of Novel Di-, Tri-, and tetranucleotide microsatellite primers suitable for genotyping various plant pathogenic Fungi with special emphasis on Fusaria and Mycospherella graminicola. Int. J. Mol. Sci. 2012, 13, 2951-2964. [CrossRef]

30. Al-Shuhaib, M.B.S.; Albakri, A.H.; Alwan, S.H.; Almandil, N.B.; AbdulAzeez, S.; Borgio, J.F. Optimal Pcr primers for rapid and accurate detection of Aspergillus flavus Isolates. Microb. Pathog. 2018, 116, 351-355. [CrossRef]

31. Trinh, H.L.; Anh, D.T.; Thong, P.M.; Hue, N.T. A Simple PCR for Detection of Aspergillus flavus in Infected Food. Qual. Assur. Saf. Crop. Foods 2014, 7, 375-383. [CrossRef]

32. Perez, C.; Paul, M.; Bazerque, P. Antibiotic assay by agar-well diffusion method. Acta Biol. Med. Exp. 1990, 15, 113-115.

33. Pariona, N.; Mtz-Enriquez, A.I.; Sánchez-Rangel, D.; Carrión, G.; Paraguay-Delgado, F.; Rosas-Saito, G. Green-Synthesized copper nanoparticles as a potential antifungal against plant pathogens. RSC Adv. 2019, 9, 18835-18843. [CrossRef]

34. Laemmli, U.K. Cleavage of structural proteins during the assembly of the head of bacteriophage T4. Nature 1970, 227, 680-685. [CrossRef]

35. Rabilloud, T.; Vuillard, L.; Gilly, C.; Lawrence, J.J. Silver-staining of proteins in polyacrylamide Gels: A General overview. arXiv 2009, arXiv:0911.4458.

36. Agarwal, S.; Nath, A.K.; Sharma, D.R. Characterisation of Peach (Prunus Persica L.) cultivars using isozymes as molecular markers. Sci. Hortic. 2001, 90, 227-242. [CrossRef]

37. Vallejos, C.E. Enzyme activity staining. In Tanksley SD, Isozymes in Plant Genetics and Breeding; Orton, T.S., Ed.; Elsevier: Amsterdam, The Netherland, 1983; p. 469.

38. Evangelisti, C.; Vitulli, G.; Schiavi, E.; Vitulli, M.; Bertozzi, S.; Salvadori, P.; Bertinetti, L.; Martra, G. Nanoscale $\mathrm{Cu}$ Supported catalysts in the partial oxidation of cyclohexane with molecular oxygen. Catal. Lett. 2007, 116, 57-62. [CrossRef]

39. Vitulli, G.; Bernini, M.; Bertozzi, S.; Pitzalis, E.; Salvadori, P.; Coluccia, S.; Martra, G. Nanoscale Copper particles derived from solvated $\mathrm{Cu}$ atoms in the activation of molecular oxygen. Chem. Mater. 2002, 14, 1183-1186. [CrossRef]

40. Ponce, A.A.; Klabunde, K.J. Chemical and catalytic activity of copper nanoparticles prepared via metal vapor synthesis. J. Mol. Catal. A Chem. 2005, 225, 1-6. [CrossRef]

41. Yamaguchi, R.; Hirano, S.; Arai, Y.; Ito, T. Chitosan salt gels thermally reversible gelation of chitosan. Agric. Biol. Chem. 1978, 42, 1981-1982.

42. Rubina, M.S.; Elmanovich, I.V.; Shulenina, A.V.; Peters, G.S.; Svetogorov, R.D.; Egorov, A.A.; Naumkin, A.V.; Vasil'kov, A.Y. Chitosan aerogel containing silver nanoparticles: From Metal-Chitosan powder to porous material. Polym. Test. 2020, 86, 106481. [CrossRef]

43. Fakruddin, M.; Chowdhury, A.; Hossain, M.N.; Ahmed, M.M. Characterization of aflatoxin producing Aspergillus flavus from food and feed samples. SpringerPlus 2015, 4, 159. [CrossRef]

44. Monda, E.; Masanga, J.; Alakonya, A. Variation in occurrence and aflatoxigenicity of Aspergillus flavus from two climatically varied regions in Kenya. Toxins 2020, 12, 34. [CrossRef] 
45. Davis, N.D.; Iyer, S.K.; Diener, U.L. Improved mmethod of screening for aflatoxin with a coconut agar medium. Appl. Environ. Microbiol. 1987, 53, 1593-1595. [CrossRef]

46. Wicklow, D.T.; Shotwell, O.L.; Adams, G.L. Use of Aflatoxin-Producing ability medium to distinguish aflatoxin-producing strains of Aspergillus flavus. Appl. Environ. Microbiol. 1981, 41, 697-699. [CrossRef]

47. Reddy, K.R.N.; Surendhar Reddy, C.; Nataraj Kumar, P.; Reddy, C.S.; Muralidharan, K. Genetic Variability of Aflatoxin B1 producing Aspergillus flavus strains isolated from discolored rice grains. World J. Microbiol. Biotechnol. 2008, 25, 33-39. [CrossRef]

48. Abbas, H.K.; Weaver, M.A.; Zablotowicz, R.M.; Horn, B.W.; Shier, W.T. Relationships between Aflatoxin production and sclerotia formation among isolates of aspergillus section flavi from the mississippi delta. Eur. J. Plant Pathol. 2005, 112, 283-287. [CrossRef]

49. Lai, X.; Zhang, H.; Liu, R.; Liu, C. Potential for Aflatoxin B1 and B2 Production by Aspergillus flavus strains isolated from rice samples. Saudi J. Biol. Sci. 2015, 22, 176-180. [CrossRef] [PubMed]

50. Yu, J.; Ehrlich, K. Aflatoxins-Biochemistry and Molecular Biology; USDA/ARS, Southern Regional Research Center: New Orlenas, LA, USA, 2011.

51. Caceres, I.; Khoury, A.A.; Khoury, R.E.; Lorber, S.; Oswald, I.P.; Khoury, A.E.; Atoui, A.; Puel, O.; Bailly, J.-D. Aflatoxin Biosynthesis and genetic regulation: A review. Toxins 2020, 12, 150. [CrossRef]

52. Mageshwari, K.; Sathyamoorthy, R. Flower-Shaped CuO nanostructures: Synthesis, characterization and antimicrobial activity. J. Mater. Sci. Technol. 2013, 29, 909-914. [CrossRef]

53. Kaur, P.; Thakur, R.; Barnela, M.; Chopra, M.; Manuja, A.; Chaudhury, A. Synthesis, Characterization andin vitroevaluation of cytotoxicity and antimicrobial activity of chitosan-metal nanocomposites. J. Chem. Technol. Biotechnol. 2014, 90, 867-873. [CrossRef]

54. Saharan, V.; Sharma, G.; Yadav, M.; Choudhary, M.K.; Sharma, S.S.; Pal, A.; Raliya, R.; Biswas, P. Synthesis and In Vitro antifungal efficacy of $\mathrm{Cu}-\mathrm{Chitosan}$ nanoparticles against Pathogenic Fungi of tomato. Int. J. Biol. Macromol. 2015, 75, 346-353. [CrossRef]

55. Mekawey, A.I.I. Effects Of Chitosan Nanoparticles as antimicrobial activity And on mycotoxin production. Acad. J. Agric. Res. 2018, 6, 101-106.

56. Kulatunga, D.; Dananjaya, S.; Godahewa, G.; Lee, J.; De Zoysa, M. Chitosan silver nanocomposite (CAgNC) as an antifungal agent against Candida Albicans. Med. Mycol. 2016, 55, 213-222. [CrossRef]

57. Alghuthaymi, M.A.; Abd-Elsalam, K.A.; Shami, A.; Said-Galive, E.; Shtykova, E.V.; Naumkin, A.V. Silver/Chitosan nanocomposites: Preparation and characterization and their fungicidal activity against dairy cattle toxicosis Penicillium expansum. J. Fungi 2020, 6, 51. [CrossRef] [PubMed]

58. Wu, Y.H.; Lee, Y.H.; Shih, H.Y.; Chen, S.H.; Cheng, Y.C.; Chiu, D.T.Y. Glucose-6-Phosphate dehydrogenase is indispensable in embryonic development by modulation of Epithelial-Mesenchymal transition via the NOX/Smad3/miR-200b Axis. Cell Death Dis. 2018, 9, 1-14. [CrossRef] [PubMed]

59. Ho, H.; Cheng, M.; Chiu, D.T. Glucose-6-Phosphate Dehydrogenase- from oxidative stress to cellular functions and degenerative diseases. Redox Rep. 2007, 12, 109-118. [CrossRef] [PubMed]

60. De Lillo, A.; Cardi, M.; Landi, S.; Esposito, S. Mechanism(s) of Action of heavy metals to investigate the regulation of plastidic Glucose-6-Phosphate dehydrogenase. Sci. Rep. 2018, 13481. [CrossRef]

61. Lin, H.-R.; Wu, C.-C.; Wu, Y.-H.; Hsu, C.-W.; Cheng, M.-L.; Chiu, D.T.-Y. Proteome-Wide dysregulation by Glucose-6-Phosphate Dehydrogenase (G6PD) reveals a novel protective role for G6PD in Aflatoxin B1-Mediated cytotoxicity. J. Proteome Res. 2013, 12, 3434-3448. [CrossRef]

62. Ibraheem, O.; Adewale, I.O.; Afolayan, A. Purification and properties of glucose 6-Phosphate dehydrogenase from aspergillus aculeatus. BMB Rep. 2005, 38, 584-590. [CrossRef]

63. Savi, G.D.; Scussel, V.M. Inorganic compounds at regular And nanoparticle size and their Anti-Toxigenic Fungi activity. J. Nanotechnol. Res. 2014, 97, 589-598.

64. Ammar, H.A.; Rabie, G.H.; Mohamed, E. Novel fabrication of gelatin-encapsulated copper nanoparticles using aspergillus versicolor and their application in controlling of rotting plant pathogens. Bioprocess Biosyst. Eng. 2019, 42, 1947-1961. [CrossRef]

(C) 2020 by the authors. Licensee MDPI, Basel, Switzerland. This article is an open access article distributed under the terms and conditions of the Creative Commons Attribution (CC BY) license (http://creativecommons.org/licenses/by/4.0/). 